\title{
Externalities of
}

Transportation Fuels: Assessing Trade-offs Between Petroleum and Alternatives

Dileep K. Birur, Robert H. Beach,

Ross J. Loomis, Sealy Chipley, Michael P. Gallaher, and David C. Dayton

July 2013 


\section{About the Authors}

Dileep K. Birur, PhD, is a research economist in the Agriculture, Resource \& Energy Economics and Policy Program at RTI International. His research includes economic modeling of the agriculture and energy sectors in partial and general equilibrium frameworks.

Robert H. Beach, PhD, directs RTI's Agriculture, Resource \& Energy Economics and Policy Program at RTI. His research includes developing and applying economic models to analyze agricultural, environmental, and

natural resource regulations, programs, and policies.

Ross J. Loomis, MS, is a senior economist in RTI's Ecosystem Services Research Program. His research includes analyzing and modeling markets for ecosystem services; valuing nonmarket goods; and conducting benefit-cost and economic impact analyses, advanced statistical and spatial analyses, and industry assessments.

Sealy Chipley, BS, is an environmental scientist, formerly with RTI, and is founder of Chipley Consulting.

Michael P. Gallaher, PhD, is the senior director of RTI's Center for Environmental, Technology, and Energy Economics. His research includes R\&D and environmental policy analysis, with a focus on evaluating new technologies and their associated economic and environmental impacts.

David C. Dayton, PhD, manages the biofuels program in RTI's Engineering and Technology Unit. His research focuses on alternative fuels research, particularly synthesis gas conversion, cleanup, and conditioning, and experimental programs related to biomass thermochemical conversion for biofuel production.

This publication is part of the RTI Research Report series. Occasional Papers are scholarly essays on policy, methods, or other topics relevant to RTI areas of research or technical focus.

RTI International

3040 Cornwallis Road

PO Box 12194

Research Triangle Park, NC

27709-2194 USA

Tel: $\quad+1.919 .541 .6000$

Fax: $\quad+1.919 .541 .5985$

E-mail:_rtipress@rti.org

Web site: www.rtiorg
RTI Press publication OP-0013-1307

This PDF document was made available from www.rti.org as a public service of RTI International. More information about RTI Press can be found at http://www.rti.org/rtipress.

RTI International is an independent, nonprofit research organization dedicated to improving the human condition by turning knowledge into practice. The RTI Press mission is to disseminate information about RTI research, analytic tools, and technical expertise to a national and international audience. RTI Press publications are peer-reviewed by at least two independent substantive experts and one or more Press editors.

\section{Suggested Citation}

Birur, D. K., Beach, R. H., Loomis, R. J., Chipley, S., Gallaher, M. P., \& Dayton, D. C. (2013). Externalities of transportation fuels: Assessing trade-offs between petroleum and alternatives. (RTI Press publication No. OP-0013-1307.) Research Triangle Park, NC: RTI Press. Retrieved from http://www.rti.org/rtipress

(C2013 Research Triangle Institute. RTI International is a trade name of Research Triangle Institute.

All rights reserved. This report is protected by copyright. Credit must be provided to the author and source of the document when the content is quoted. Neither the document nor partial or entire reproductions may be sold without prior written permission from the publisher.

doi:10.3768/rtipress.2013.op.0013.1307

www.rti.org/rtipress 


\section{Externalities of Transportation Fuels: Assessing Trade-offs Between Petroleum and Alternatives}

\author{
Dileep K. Birur, Robert H. Beach, Ross J. Loomis, \\ Sealy Chipley, Michael P. Gallaher, and David C. Dayton
}

\footnotetext{
Abstract

This research report examines the economic and environmental externalities associated with the US transportation sector. The United States currently accounts for about 25 percent of world oil consumption, about 50 percent of which is imported. Achieving energy security by reducing dependence on imported oil has been the foremost challenge of several major energy-importing countries, including the United States. In this study, we explored the costs associated with energy security/cost of dependence on oil and estimated the environmental externalities associated with different types of transportation fuels based on a set of economic, environmental, and life-cycle analysis models. Our assessment of estimations on oil dependence costs indicates that several elements constitute the true cost of oil and not many studies have attempted to include all of these costs for various reasons. For analyzing the environmental externalities, we used GREET, a life-cycle analysis model; the FASOM-GHG model of agriculture and forestry; APEEP — an integrated assessment model to calculate the marginal damage of emissions; GTAP-BIO—a computable general equilibrium model to estimate land use changes; and the OSIRIS model to estimate the species extinctions based on deforestation. This study on assessing the externalities could provide a quantitative basis for policy initiatives pertaining to America's future transportation infrastructure. This study suggests that there is a need to consider economic, environmental, and other societal costs within a holistic framework to assess relative costs and benefits and suitability of alternative transportation fuels that could play a role in meeting our future energy needs.
}

\section{Contents \\ Introduction}

Addressing the Energy Security Challenge

Why the Transportation Sector? 3

\section{Energy Security}

Dependence on Foreign 0il 5

Volatility in Oil Prices 8

Oil Security Premium 9

Accounting for the US

Monopsony Cost

Subsidies for Transportation Fuels

National Security Costs of Securing Energy

Externalities of Energy

Environmental Externalities of Transportation Fuels

A Review of Environmental Externalities of Fossil Fuels 17

A Review of Environmental Externalities of Renewable Fuels

Life-Cycle Assessment (LCA) 25

Impact of Transportation Fuels on Water Use

Health Impacts of Transportation Fuels 31

Sustainability Criteria

Conclusions

Recommendations for Further Research

References

Appendix 


\section{Introduction}

Alternative transportation fuels are expected to become increasingly competitive over time as the finite supply of petroleum resources is depleted and the prices of fossil fuels are driven upward. However, negative externalities and economic impacts associated with the use of petroleum-based fuels provide a rationale for considering policy interventions to speed the transition to alternative fuels. As oil prices have trended upward and experienced greater volatility in the past decade, concerns have again been raised over our dependence on foreign energy sources and the expanding US trade deficit. The Renewable Fuels Standard (RFS), crafted under the Energy Policy Act (EPAct) of 2005, mandated the first US renewable fuel volume of 7.5 billion gallons of renewable fuel to be blended with gasoline by 2012. This policy was expanded as RFS2 under the Energy Independence and Security Act (EISA) of 2007 with the annual volume requirements of 36 billion gallons of renewable fuels by 2022 (US Environmental Protection Agency [US EPA]/Office of Transportation Air Quality [OTAQ], 2012).

Despite efforts to reduce dependence on imported energy sources over the past few decades through a variety of strategies, the share of imports in US oil consumption gradually escalated from a mere 21 percent in 1970 to over 60 percent during the past decade. With 5 percent of global population and 2 percent of oil reserves, the United States currently accounts for about 25 percent of world oil consumption, of which more than 50 percent comes from imports. On the global scale, about 45 percent of world oil production was consumed by the transportation sector in 1973, increasing to 61 percent in 2007 (Figure 1). This trend has been attributed primarily to growing global motorization and international trade. The share of oil consumption in nonenergy sectors, such as the petrochemical industry (plastics and fertilizers), has also grown slightly in the past three decades. The share of oil consumption from other sectors, including powering of farm equipment, power generation, and heating oil in residential use, has declined over that time.

One offshoot of these events has been the development of policy incentives promoting the growth of alternative transportation fuels, not only in the United States, but across the world. However, we remain highly dependent on imported oil. In 2011, the United States imported 3.24 billion barrels of crude oil at a cost of $\$ 330$ billion (US Department of Energy [DOE]/Energy Information Administration [EIA], 2011a). President Obama, in his blueprint for energy security, described a vision of reducing US dependence on oil, combating pollution, and creating jobs by investing in clean-energy technologies (The White House, 2010). Key goals in moving toward this vision include reducing US oil imports by one-third by 2025 and implementing the New Clean Energy Standard for America, which aims to achieve a goal of having 80 percent of US electricity generation come from clean energy sources (e.g., wind, solar, clean coal, nuclear power) by 2035 .

Figure 1. Distribution of world oil energy consumption by sector

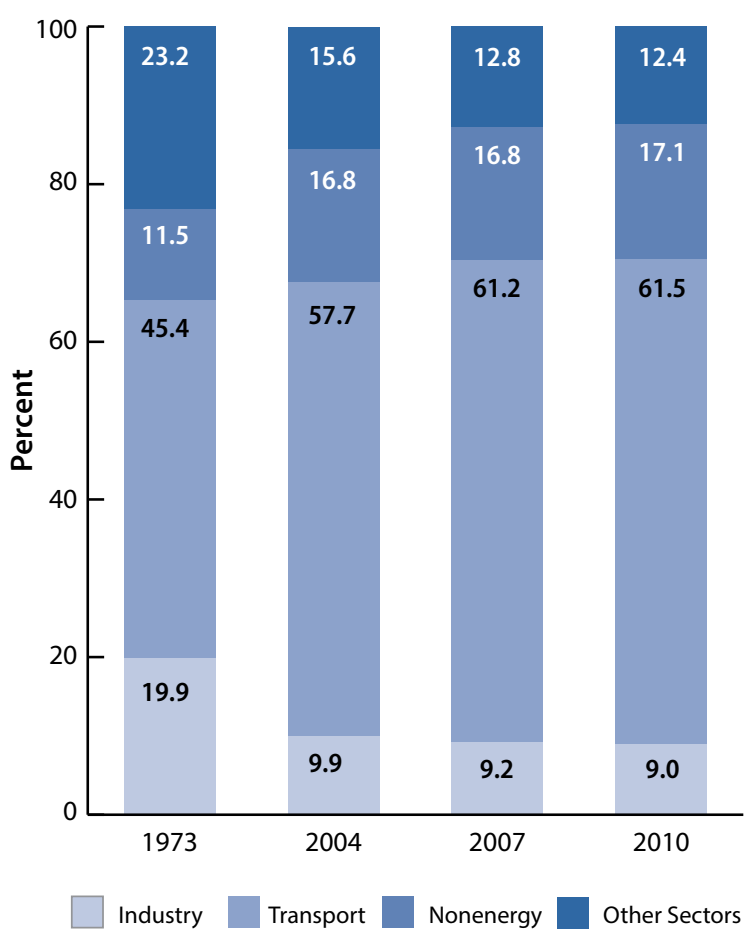

Source: IEA (2011b).

Not only is the quantity of oil being imported of grave concern, but also the vulnerability of the US economy to the volatility in oil price and supply. Recently, energy experts predicted that oil prices could soar by 50 percent or more within a few days 
over concerns regarding greater instability in oil markets when Iran threatened to block the Strait of Hormuz (Krauss, 2012). Although more than 85 percent of oil and natural gas that flows through the Strait goes to Asian countries, the ripple effect on the global oil price would severely affect the US trade deficit and national security. Several researchers have calculated the negative effects of higher oil prices on the US aggregate economy in the past decade (Hamilton, 2011; Ramey \& Vine, 2011; Blanchard \& Riggi, 2009). Copulos (2003) estimated that the cumulative economic impact of oil supply disruptions for the three decades since 1973 is about $\$ 2.5$ trillion. A recent estimate by Greene, Lee, and Hopson (2011) revealed that the cumulative direct cost of oil dependence from 2005 to 2010 alone is about \$2.1 trillion. In recent years, energy security has become a global concern because many fast-growing Asian economies also depend on imports for a large share of their oil consumption. This poses a great challenge and opportunity to develop sustainable technologies that reduce dependence on oil.

\section{Addressing the Energy Security Challenge}

Three vital issues need to be considered when addressing the energy problem: externalities, sustainability, and energy security. If we start with the primary focus of achieving energy security (e.g., by reducing dependence on oil, developing alternatives, improving energy efficiency), we must account for the economic and environmental externalities associated with alternative energy technologies (Figure 2).

Figure 2. The energy trilemma of the 21 st century

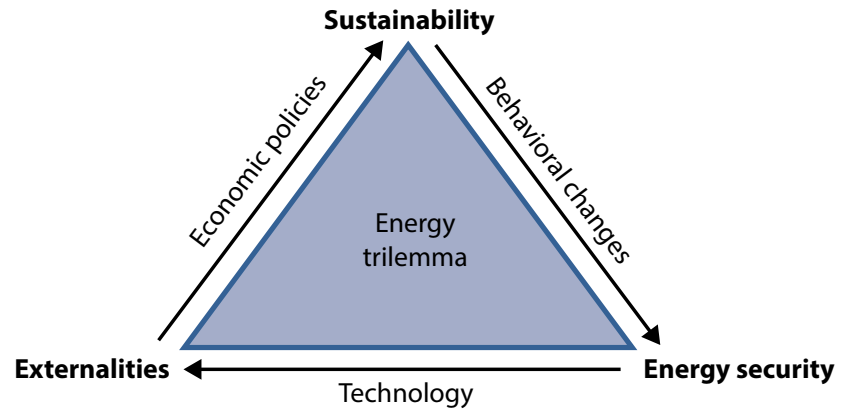

Source: Based on World Energy Council (2012) and E.ON (2012).

Economic externalities refer to the social benefits derived and costs incurred from production of energy until its end use that are not reflected within the market price. For example, production of a particular type of biofuel in the United States is expected to contribute toward energy security by reducing oil imports, improving the balance of trade, reducing national security costs, and helping the rural economy. These are the positive externalities. In contrast, the negative externalities are the cost of subsidies, tax credits, the capital cost of infrastructure such as refineries and pipelines established across the country, and higher feedstock prices, which could help farmers but hurt the animal feed and food industries. The environmental externalities include impacts on natural resources and greenhouse gas (GHG) emissions. After accounting for the costs and the environmental impacts of an energy system, another vital issue is to ensure that the chosen energy sources would lead us toward a sustainable future. Sustainability, in turn, depends on consumers' attitudes toward a particular energy source (e.g., buying hybrid vs. conventional cars, commuting by mass transportation). In moving toward energy security, it is important to address the energy trilemma bounded by these three issues with a focus on transportation fuels.

\section{Why the Transportation Sector?}

Oil has been the predominant source of energy for transportation with very limited and nascent alternatives. In the United States in 2009, about 72 percent of oil was used for transportation, 22 percent for industrial uses, 5 percent for residential and commercial uses, and 1 percent for electric power. As Figure 1 shows, globally about 61 percent of oil energy was consumed by the transportation sector in 2007, which was a gradual increase from only 45 percent in 1973. Despite technological advancements to develop alternative fuels, the use of petroleum products in US transportation is likely to continue increasing. The International Energy Agency (IEA) (2011b) estimates that US transportation energy consumption will increase from 29 quadrillion Btu (QBtu) in 2007 to 33 QBtu in 2035. Their reference case estimate assumes adoption of appliance efficiency standards such as the US EPA-proposed corporate average fuel economy (CAFE) standards and the GHG emission standards issued by the National Highway Traffic Safety Administration (NHTSA) for light-duty vehicles. 
More recent estimates from the US DOE/EIA (2012a) indicate that energy consumption in the US transportation sector is likely to increase less, from 27.6 QBtu in 2012 to only 28.8 QBtu in 2035 (Figure 3). This lower projected level of transportation energy consumption is mainly attributed to an increase in the fuel economy of highway vehicles and also a reduction in vehicle-miles traveled because of lower projected economic growth and employment rates than assumed by the IEA (2011b). However, among energy users, the transportation sector continues to play a prominent role as a result of continued growth in energy consumption and its substantial economic and environmental externalities.

\section{Figure 3. Delivered energy consumption by sector in the United States (QBtu)}

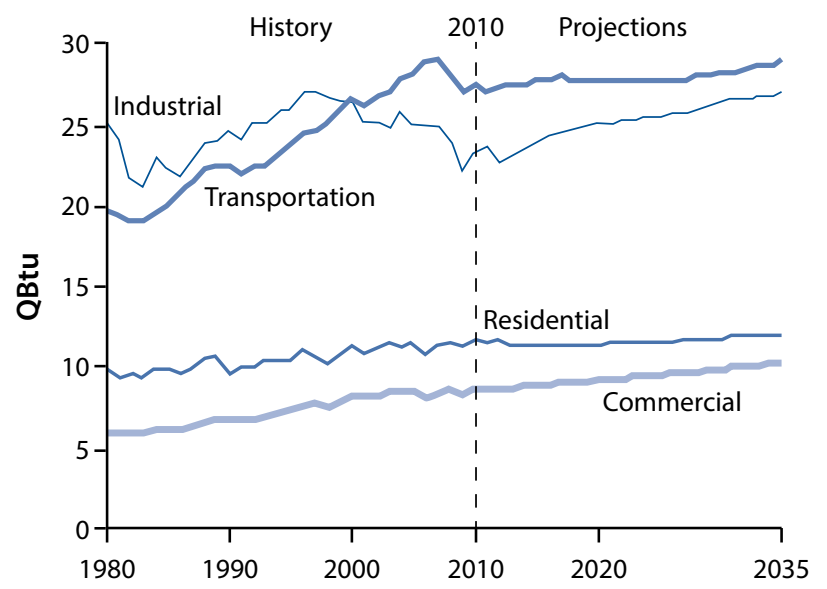

Source: IEA (2011b).

In 2004, the global transportation sector derived 95 percent of its energy from petroleum and contributed 23 percent of energy-related GHG emissions (Kahn et al., 2007). In 2009, GHG emissions from the US transportation sector accounted for 27 percent of national emissions, representing the second largest source after the electricity sector (US EPA, 2010). Furthermore, the national security cost of defending the global oil supply has drawn much attention in recent years. Although several studies have looked at the economic impacts and environmental externalities of transportation fuels, they have typically focused on either petroleum fuels or alternative fuels in isolation and generally have examined only a subset of fuels and selected economic impacts and externalities.
Because several technologies are in the race for alternative fuels at the pump, it is important to understand the complex subsidies and externalities related to transportation fuels because they may result in unintended impacts on the environment and the economy. This study highlights the security and national defense, economic, health, water use, and other environmental impacts associated with various transportation fuels. Specifically, we explore the energy security costs involved in terms of subsidies/ tax credits and national defense expenditures attributed to secure energy resources and develop a decision support mechanism based on economic models and a life-cycle assessment (LCA) model to estimate the key environmental externalities such as GHG emissions and biodiversity loss across different transportation fuels.

\section{Energy Security}

Energy security is an increasing concern because it is a vital part of national security policy. The term "energy security" has frequently been used in the spirit of justifying a policy or a technology. For instance, it is often used both in the context of reducing foreign imports of energy resources and with reference to technologies to diversify domestic energy production. Loschel, Moslener, and Rubbelke (2010) identified three major reasons for a frequent use/abuse of the energy security concept: (a) it is important to the major economies, (b) it is a complex and interrelated issue, and (c) it lacks well-defined ideas supporting it. In the ambit of these reasons, we have highlighted the approaches to address energy security issues in the literature.

Although energy security is a much broader issue, it is often defined in the ambit of dependence on oil. Ever since the energy crisis of the 1970s due to the oil embargo, US energy analysts have raised concerns about our level of dependence on foreign oil and its potential risk to national security. As the price of oil rises, the US trade deficit swells because petroleum imports account for such a large share of the deficit. For instance, the petroleum-related US trade deficit in 2010 was $\$ 265$ billion, which accounted for 42 percent of the total deficit in goods. This section addresses issues related to dependence on foreign 
oil, volatility in oil prices, oil security premiums, US monopsony cost, subsidies for transportation fuels, and national security costs.

As defined by Staley, Ladislaw, Zyla, and Goodward (2009) and Wicks (2009), energy security must ensure the following:

- Physical security-avoidance of involuntary interruptions of supply, diversity in suppliers, diversified and reliable energy sources

- Price security-relatively stable and affordable price to consumers

- Geopolitical security-having foreign policies independent of energy supply

\section{Dependence on Foreign Oil}

Several recent studies on energy security issues have focused primarily on the determinants of oil price volatility and its impact on various measures of the US macro economy such as consumption, investment, and employment. In 2011, crude oil production in the United States was 5.67 million barrels per day (mbpd), and we imported about $8.87 \mathrm{mbpd}$ of oil at a cost of about $\$ 1$ billion a day (US DOE/EIA, $2012 \mathrm{~b}$ ). US production and net imports of petroleum and other liquid fuels over the past six decades are displayed in Figure 4. As shown in this figure, US production of liquid fuels peaked in the early 1970s, and the share of imports started expanding afterward. The peak imports (dependency) were in 2006 when the share of imports constituted 60 percent of US consumption, although it fell to 45 percent in 2011. Part of this reduction in imports was due to the decrease in overall US consumption of liquid fuels by 9.2 percent during the 2007 to 2009 period, owing to the economic recession. From 2007 to 2011, the domestic production of liquid fuels, including petroleum and biofuels, increased by 21.6 percent.

Currently, about 25 percent of the crude oil imported into the United States comes from Canada, followed by Saudi Arabia (14 percent), Mexico (13 percent), Venezuela (11 percent), Nigeria (10 percent), and Iraq

\section{Figure 4. Production and net imports of petroleum and other liquids in the United States}

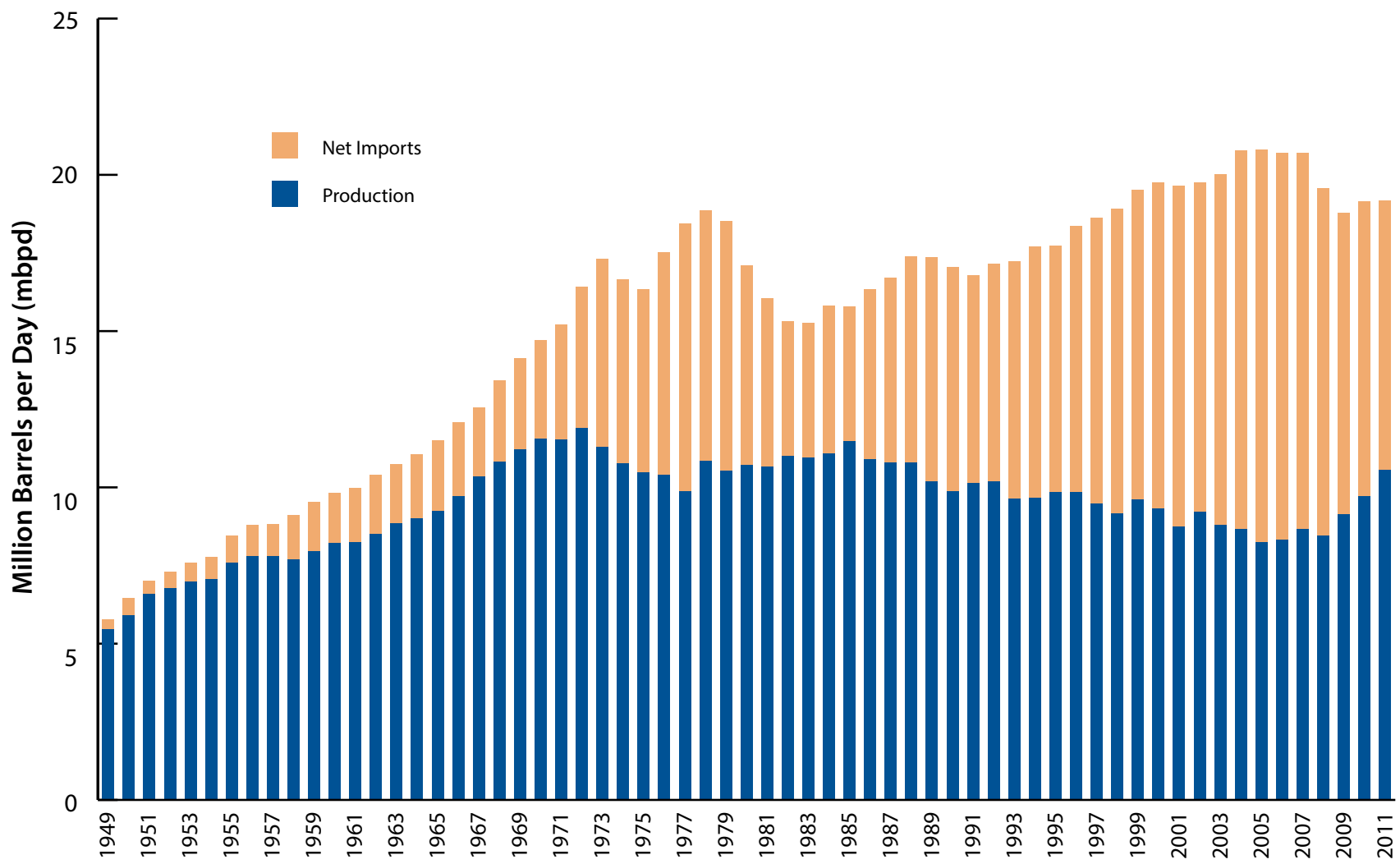


(6 percent), with another 10 countries combining to constitute the other 21 percent of US imports. According to IEA (2011b) forecasts, under their New Policies Scenario (that assumes recent policies announced by national governments are successfully implemented), the Middle East and North African (MENA) region is set to supply the bulk of the growth in oil output through 2035, while oil extraction in other regions such as Russia, Mexico, Europe, and China becomes increasingly costly. As a result, the price of oil is likely to be higher in the future because of rising transportation demand coupled with greater upstream costs. Because nearly half of the oil imports come from politically unstable economies such as Saudi Arabia, Venezuela, Nigeria, and Iraq, this situation poses greater vulnerability to oil price fluctuations and leaves the nation's energy as well as national security at risk.

Researchers have analyzed the potential impact of higher oil prices on the US economy based on oil expenditures as a share of gross domestic product (GDP). Figure 5 displays the trend in the share of expenditures on petroleum consumption or imports to the US nominal GDP over the past six decades. These shares are also compared with the crude oil price over the same period. Historically, the share of expenditures has spiked significantly whenever the oil price has been high.

The historical average share of expenditures on petroleum consumption is 2.75 percent and that of petroleum imports is 0.98 percent. This share helps in understanding the response of GDP with respect to changes in petroleum consumption. As Figure 5 shows, the petroleum costs (both total consumption and imports) as a share of GDP were below the historical average during most of the late 1980s through 2001. Interestingly, when the share of petroleum costs to GDP is higher in a particular year, the growth of US nominal GDP falls sharply in the subsequent year. Although other economists may include somewhat different components in their calculation of these petroleum costs (discussed in subsequent sections), Greene (2010) and Greene et al. (2011) argue that this time frame can be considered

\section{Figure 5. Share of petroleum imports and consumption to US GDP}

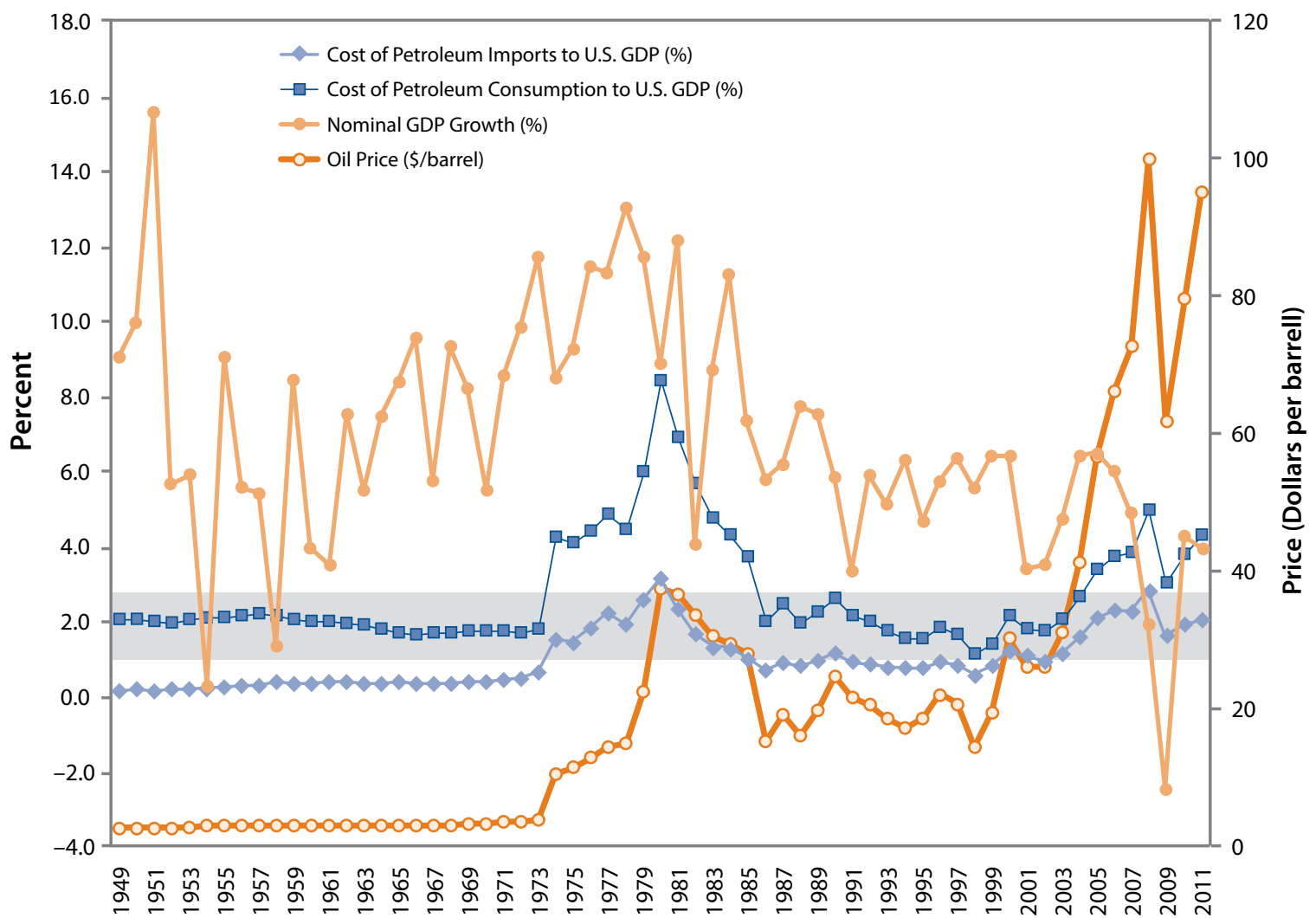


a period of US “oil independence." Greene (2010) makes the case that measures of oil dependence cannot be based merely on the share of imports, but that dependence is a function of a combination of factors: (a) a noncompetitive world oil market strongly influenced by the Organization of Petroleum Exporting Countries (OPEC) cartel, (b) high levels of US imports, (c) the importance of oil to the US economy, and $(\mathrm{d})$ the lack of economical and readily available substitutes for oil.

The National Academy of Sciences (NAS) (2009) compiled estimates of US oil dependence since 1990 and projections for 2030 (Table 1). US petroleum consumption in 1990 was $17 \mathrm{mbpd}$, constituting about 26 percent of world oil supply, and it is projected to increase to $22.8 \mathrm{mbpd}$, constituting 22 percent of world oil supply in 2030. Although the world oil price forecast for 2030 in the NAS study is only $\$ 60 /$ barrel in 2007 dollars (which is unlikely considering the latest US DOE/EIA [2012a] forecast for the reference case suggests close to $\$ 150 /$ barrel), it is important to note the rising share of OPEC oil supply to more than 46 percent by 2030 .

However, oil intensity (measured as 1,000 Btus of oil consumption per dollar of GDP) is estimated to fall from 3.4 in 2007 to 2.2 by 2030 . Similarly, US oil intensity measured as a share of GDP is projected to fall from 3.6 in 2007 to 1.9 by 2030 , implying that the importance of oil to the US economy is likely to decline despite rising consumption. Greene (2010) argued that "energy independence will be achieved when the annual economic costs of oil dependence are less than 1 percent of US GDP, with 95 percent probability" (p. 1615). Although total consumption of petroleum in the United States and imports have dropped since 2007 (Figure 4), petroleum costs as a share of GDP have risen in recent years (Figure 5). Oil prices have risen more rapidly than consumption has fallen, leading to higher total oil expenditures.

Empirical studies suggest that higher energy prices have historically affected economic growth. Because oil security premiums are directly affected by oil prices, it is important to understand the relationship between oil price and the US GDP. Studies based on econometric estimation have found that the response of US GDP to oil price shocks (elasticity) is about -0.044 with a lower and upper bound of -0.012 to -0.078 , respectively (Brown \& Huntington, 2010). This coefficient, estimated based on log linear functional form, indicates the percentage change in GDP due to a 1 percent change in the price of oil. The findings in the literature indicate that this elasticity estimate has decreased for the data from recent decades relative to data from the 1970s, signifying a declining importance of oil to the US economy. Hamilton (2011) noted that previous 10 out of 11 US recessions since World War II were preceded by spikes in oil prices. His estimations on the response of real GDP growth rates to lagged oil prices were negative and highly statistically significant. He further showed that US real GDP growth can be predicted one-quarter ahead by including an appropriately defined lagged nominal price of oil. In the context of the oil crisis and economic growth during the 1970s, Kopits (2009) pointed out that the US economy has tended to grow well when the share of oil consumption expenditures to GDP was less than 2 percent. The author indicated that whenever oil consumption expenditures crossed 4 percent

\begin{tabular}{|c|c|c|c|c|}
\hline & 1990 & 2000 & 2007 & 2030 \\
\hline Net oil imports as percentage of total US supply & 42.2 & 52.9 & 58.2 & 55.5 \\
\hline World oil price (2007 \$/bbl) & 38 & 35 & 72 & 60 \\
\hline World crude production (mbpd) & 65.5 & 74.9 & 81.5 & 102.9 \\
\hline OPEC share (percentage) & 38.3 & 42.9 & 43.2 & 46.4 \\
\hline US petroleum consumption (mbpd) & 17 & 19.7 & 20.7 & 22.8 \\
\hline US share of world production (percentage) & 26 & 26.3 & 25.4 & 22.2 \\
\hline Oil intensity (1,000 Btu per $\$ 1$ of GDP) & 4.7 & 3.9 & 3.4 & 2.2 \\
\hline Oil intensity (value of oil as a percentage of GDP) & 2.6 & 2.0 & 3.6 & 1.9 \\
\hline
\end{tabular}


of GDP, the United States experienced a recession. For instance, oil expenditures represented about a 3 percent drag in the growth on the economy during the 1970s. The recent US recession, which extended from December 2007 through June 2009, was also preceded by oil hitting $\$ 80$ per barrel and the oil cost share crossed the 4 percent threshold.

\section{Volatility in Oil Prices}

Rising oil prices can potentially affect the US economy. Volatility in oil prices could significantly affect any large oil-importing country by affecting its balance of trade. Uncertainty in oil supply, particularly due to recent political unrest in the MENA region, has exacerbated oil price spikes. Recently, energy experts predicted that Iran's threat to close the Strait of Hormuz could raise oil prices 50 percent within a few days (Krauss, 2012). Even a partial blockade by Iran could not only severely affect the energy supply to major importers such as China, Japan, and other Asian countries, thereby threatening global energy security, but also pose a risk to US economic interests in the Gulf region. In moving toward a path of energy independence, Rao (2012b) asserted that US imports of about $1.7 \mathrm{mbpd}$ oil passing through the Strait could be replaced by establishing gas-to-liquid (GTL) plants, additional pumping of unconventional oils through the TransAlaska Pipeline System, fuel switching to liquefied natural gas (LNG) or methanol by long-haul trucks, renewable fuels, and displacement of diesel by compressed natural gas (CNG).

Figure 6 displays the annual average West Texas Intermediate (WTI) spot price and Brent crude price over the past 25 years. WTI is lighter and of higher quality than Brent crude, with lower sulfur content ( 0.24 percent versus up to 4.5 percent of Brent crude). Because WTI is extracted and refined within the United States, Brent crude is considered an international benchmark.

As the figure illustrates, historically the prices of these crude oil markets have moved very closely together, although the gap between WTI and Brent prices began widening in late 2010. As Tverberg (2012) indicates, the main reason for the lower WTI price

\section{Figure 6. Crude oil prices-WTI spot price and Brent spot price}

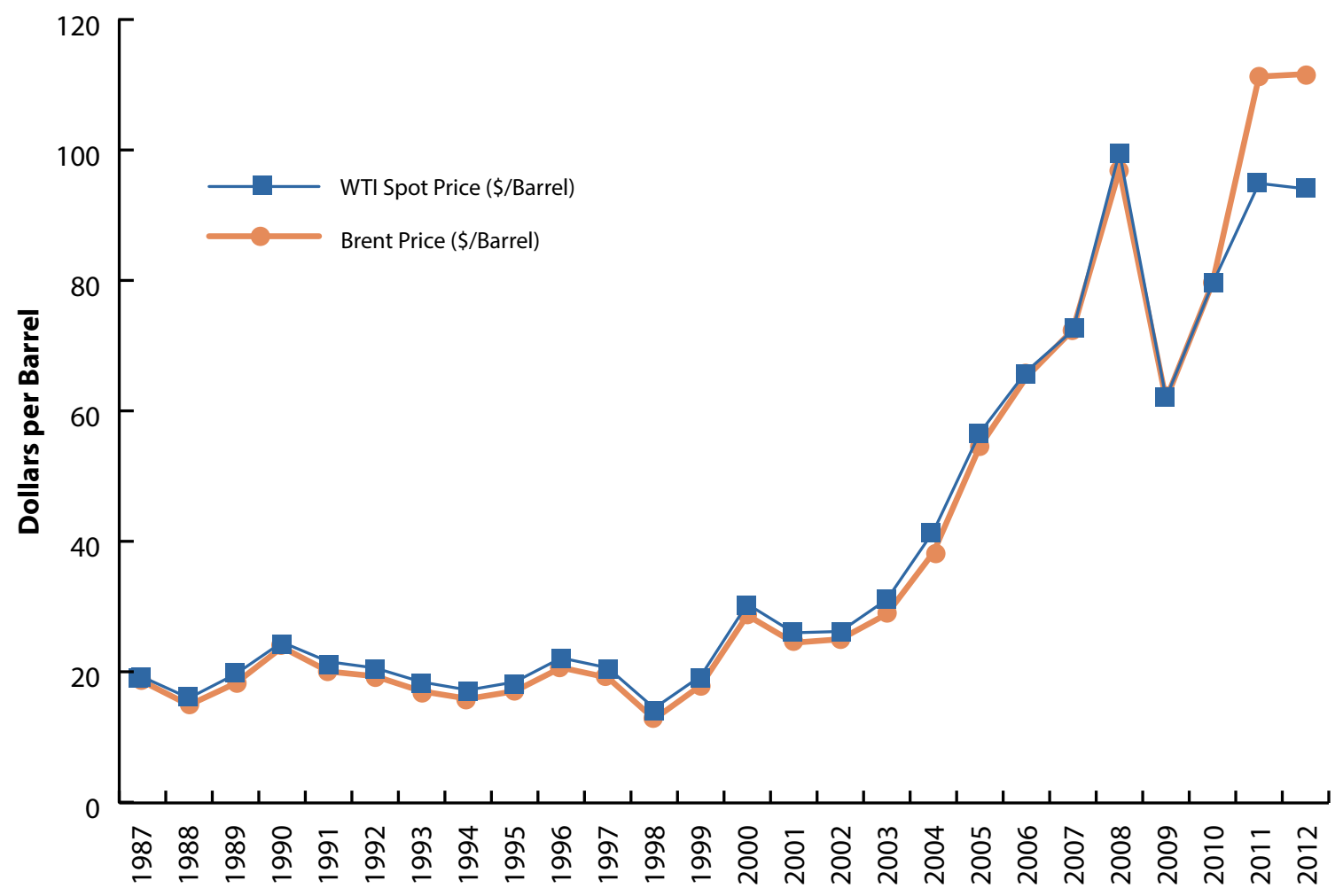


in recent years is an oversupply of crude oil in the Midwest from Canadian imports supplied through two pipelines with a total capacity of $1.63 \mathrm{mbpd}$. Although the WTI price in the United States has been around $\$ 20$ cheaper than Brent crude oil, the import costs in the United States have risen because of higher Brent crude price. Because the oversupply of Canadian oil in the Midwest is a major cause of the lower WTI price, it is expected to move closer to the Brent price if the total oil supply drops such that refineries in the Midwest could use the locally produced oil.

Another factor that is supportive of higher crude oil prices is the weakness in the US dollar. Because most of the oil exporters receive their revenues in US dollars and use this revenue to import goods and services from other countries by making payments in their respective currencies, any change in value of the US dollar directly affects their real income and therefore the purchasing power of the oil-exporting countries. Any change in the value of the US dollar is likely to have short-term and long-term implications on the oil market. In the short term, a falling dollar may not affect oil prices much, but it can influence the speculation and investment decisions on the oil futures markets by attracting investors anticipating higher yields and vice versa. However, in the long run, a weaker dollar can affect the market by increasing consumption (demand), especially in regions with appreciating currencies, and it can constrain supply by reducing production as a result of lower receipts. The net effect would be an increase in oil prices.

\section{Oil Security Premium}

The term "oil security premium" has been defined from several perspectives. Brown and Huntington (2010) defined it as a quantification of externality portions of the economic losses associated with the potential disruptions of supply that occur because of increased consumption of either domestic or imported oil. Oil security premium is also defined as the marginal external costs of petroleum consumption (Leiby, 2008). Parry and Darmstadter (2003) defined oil security premium as the difference between the costs incurred by the US economy as a whole and the costs incurred by individuals or firms from additional oil consumption. Those authors argue that the oil premiums indicate how much oil should be taxed after accounting for all the social costs of oil consumption such as local and global air pollution, traffic congestion, and accidents.

Before we look at the oil security premium, it is interesting to explore the oil extraction/production cost across different regions in the world. The regions with relatively lower production and finding costs have greater leverage to receive higher premiums on their exported oil. As reported by US DOE/EIA (2011c), the lifting cost of crude oil in the United States is only $\$ 8.50 /$ barrel of oil equivalent (boe) in 2009 dollars (Table 2). The lifting cost is the cost incurred to operate and maintain wells and related equipment and facilities to produce oil and gas. The total production cost includes the direct lifting costs and the production taxes. The average production tax

Table 2. Production cost and finding cost of crude oil (2007-2009) (2009\$/boe)

\begin{tabular}{lcc|c|c} 
Region & $\begin{array}{c}\text { Direct Lifting Cost } \\
\text { (a) }\end{array}$ & $\begin{array}{c}\text { Production Tax } \\
(\mathbf{b})\end{array}$ & $\begin{array}{c}\text { Total Production Cost } \\
\text { (a + b) }\end{array}$ & $\begin{array}{c}\text { Finding Costs } \\
\text { (2007-2009 average) }\end{array}$ \\
\hline USA & 8.50 & 1.78 & 10.28 & 21.58 \\
\hline Canada & 14.38 & 0.44 & 14.82 & 12.07 \\
\hline Europe & 8.96 & 1.79 & 10.75 & 42.32 \\
\hline Middle East & 5.75 & 3.17 & 8.92 & 6.99 \\
\hline Russia & 7.95 & 0.64 & 8.59 & 13.92 \\
\hline Africa & 7.31 & 2.62 & 9.93 & 35.01 \\
\hline Other eastern hemisphere & 6.31 & 1.56 & 7.87 & 7.64 \\
\hline Other western hemisphere & 4.36 & 1.32 & 5.69 & 20.43 \\
\hline Worldwide & 8.26 & 1.78 & 10.04 & 18.31 \\
\hline
\end{tabular}

Source: US DOE/EIA (2011c). 
in the United States was $\$ 1.78$ per boe, resulting in a production cost of $\$ 10.28$ per boe during the 2007 to 2009 period.

As the table shows, the production costs are cheapest in the other western hemisphere (central and south America, Caribbean), other eastern hemisphere (Asia Pacific), Russia, and Middle Eastern regions. The highest production costs are reported by Canada, followed by Europe, and then the United States. As US DOE/EIA (2011c) reported, production taxes typically vary with oil prices, affecting production costs. For instance, because of higher oil prices during 2008, production taxes dropped by 56 percent worldwide. In addition to production costs, another important cost that needs to be accounted for is the finding cost, which includes exploration and development costs for adding proven reserves of oil and natural gas. The finding costs are generally accounted for as the weighted average over a period of 3 years. As Table 2 indicates, the finding costs are highest in Europe ( $\$ 42$ per boe), followed by Africa, the United States, and the other western hemisphere region.

Table 3 offers a comparison of total production costs across different sources as estimated by IEA (2008). As discussed above, the oil fields in the MENA region have the lowest production costs, but unconventional oil, such as oil shale, gas to liquids, and coal to liquids, is associated with relatively higher production costs. With these higher production costs, advancement of

Table 3. Total production cost across different sources (2007-2009) (2008\$/boe)

\begin{tabular}{lc} 
Comparison across Other Sources & Total Production Cost \\
\hline Mideast/North Africa oilfields & $6-28$ \\
\hline Other conventional oilfields & $6-39$ \\
\hline $\begin{array}{l}\text { Carbon dioxide }\left(\mathrm{CO}_{2}\right) \text { enhanced oil } \\
\text { recovery }\end{array}$ & $30-80$ \\
\hline Deep/ultra-deep-water oilfields & $32-65$ \\
\hline Enhanced oil recovery & $32-82$ \\
\hline Arctic oilfields & $32-100$ \\
\hline Heavy oil/bitumen & $32-68$ \\
\hline Oil shale & $52-113$ \\
\hline Gas to liquids & $38-113$ \\
\hline Coal to liquids & $60-113$ \\
\hline
\end{tabular}

Source: IEA (2008). unconventional fuel technologies requires a higher break-even price of oil.

Michalek et al. (2011) indicated that the economic cost of US gasoline consumption should include at least three components: (a) risk of losses due to oil supply disruptions, (b) higher costs due to the effect of US demand on world oil prices, and (c) the cost of existing policies meant to enhance oil security. Greene (2010) argued that the cost of oil dependence is due to OPEC's noncompetitive behavior in the world oil market, which results in higher oil prices. As a result of the presence of this cartel, the US economy suffers from three kinds of economic costs: (a) transfer of wealth, (b) loss of potential to produce, and (c) disruption losses. Although transfer of wealth occurs when oil producers raise prices by using market power, it does not necessarily reduce US output. However, the other two costs reduce US GDP. Greene et al. (2011) claimed that because the costs of oil dependence are due to "market failure" of an imperfect competition, these costs should not be treated as an "externality." However, Copulos (2003) and NAS (2009) considered these "hidden costs" externalities.

Brown and Huntington (2010) estimated oil security premiums by using a range of parameter assumptions based on the US DOE\EIA's projected oil market conditions for 2015 to 2016 (Table 4). Those authors employed a welfare-analytic approach that included projected world oil market conditions, probable oil supply disruptions, and their resulting market responses, including the US economic losses that should be considered externalities. They assumed the projected world price of oil is $\$ 100$ per barrel and the US GDP is $\$ 16.315$ trillion in 2007 dollars. As the table suggests, the expected GDP loss associated with a marginal increase in the consumption of imported oil is $\$ 4.87$ per barrel, which is greater than the GDP loss of consuming domestic oil ( $\$ 3.65$ per barrel). The expected transfer of wealth is found to decline ( $\$ 0.84$ per barrel) with the increase in consumption of domestic oil and the expected transfers increase (\$0.11 per barrel) with the increase in consumption of imported oil. The total externality is the net effect of GDP loss and transfers, which was estimated to be $\$ 2.81$ for domestic oil (with a range of $\$ 0.19$ to $\$ 8.70$ ) 
and $\$ 4.98$ for imported oil (with a range of $\$ 1.10$ to \$14.35).

The fourth column of the table indicates the difference between using imported versus domestic oil. This difference is called the external security cost of displacing a barrel of domestic oil production with imported oil with oil consumption remaining constant. The total external security cost was found to be $\$ 2.17$ per barrel (with a range of $\$ 0.91$ to $\$ 5.65$ ). The range of cost estimates is based on lower- and upper-bound values of elasticity estimates. Based on projected oil prices and US GDP, the authors also estimated the oil security premiums over the period 2008 to 2030 . The midpoint estimate of the oil security premium for displacing domestic oil production with imports increased marginally from $\$ 2.17$ per barrel in 2008 to $\$ 2.37$ in 2030 .

Similar estimates of oil premium costs were reported by Parry and Darmstadter (2003). Their estimation

Table 4. Estimated oil security premiums for 2015-2016 (2007\$/barrel of oil)

\begin{tabular}{lccc} 
& Domestic & Imports & $\begin{array}{c}\text { Imports }-~ \\
\text { Domestic }\end{array}$ \\
GDP loss & $\begin{array}{c}3.65 \\
(1.77 \text { to } 10.67)\end{array}$ & $\begin{array}{c}4.87 \\
(1.03 \text { to } 14.10)\end{array}$ & $\begin{array}{c}1.22 \\
(0.26 \text { to } 3.43)\end{array}$ \\
\hline Transfers & -0.84 & 0.11 & 0.95 \\
& $(-0.58$ to -1.97$)$ & $(0.07$ to 0.25$)$ & $(0.65$ to 2.22$)$ \\
\hline Total & 2.81 & 4.98 & 2.17 \\
externality & $(0.19$ to 8.70$)$ & $(1.10$ to 14.35$)$ & $(0.91$ to 5.65$)$ \\
\hline
\end{tabular}

Source: Brown and Huntington (2010).

Note: Figures in parentheses are based on the lower- and upper-bound elasticities of US GDP to oil price.

of $\$ 5$ per barrel of oil ( 12 cents per gallon of gasoline) was assumed to reflect the risk of macroeconomic disruptions from oil price shocks and US market power in the world market. The authors also pointed out that although gasoline taxes in the United States (federal plus average of state taxes) are currently much higher than their estimated oil premium, the optimal fuel tax should be around \$1 per gallon of gasoline if we account for other social costs such as local and global air pollution, traffic congestion, and accidents.

Monopoly market power in the world oil market leads to lower levels of production than levels of production that could be attained in a competitive market. It also leads to higher oil prices with high volatility and lower social welfare. Based on empirical studies, Parry and Darmstadter (2003) indicated that OPEC supply behavior conforms more closely to an output-sharing cartel (imperfect) than a competitive model. Greene et al. (2011) argued that although a standard solution to reduce market power would be to break up the monopoly power into smaller firms that increase the competition, it is impracticable because the firms are the sovereign countries. Those authors estimated that the costs of oil dependence to the US economy mainly due to the noncompetitive behavior of the world oil market were about $\$ 500$ billion in 2008 and totaled about $\$ 2.1$ trillion over a period from 2004 to 2010. However, Arvizu and Drennen (1997) distinguished the role of government in short-term and long-term crises. In short-term crises that may be politically driven or result from temporary market disequilibrium, government action should help provide stability and predictability in the market, for example, formulation of Strategic Petroleum Reserve drawdown plans during shortterm supply interruptions. The longer-term crises may arise because of issues such as diminishing oil reserves, increasing concentration of remaining reserves in politically unstable regions, increasing demand from other regions such as Asia, and rising global concerns to reduce GHG emissions. Although government actions under these crises would differ strategically, the overall goal should be to move toward more elastic oil prices so that higher oil prices could lead to decreased demand for oil. This fall in demand would ease upward pressure on oil and encourage alternative sources of transportation.

\section{Accounting for the US Monopsony Cost}

Because the United States is the largest oil consumer in the world, studies on energy security cost estimations have included the monopsony cost and macroeconomic disruptions. Any US domestic policy that reduces the demand for oil is expected to reduce the world price of oil and thus benefit the United States through lower prices on the subsequent oil imports (NAS, 2009). Parry and Darmstadter (2003) argued that if the United States were a price taker in the world market, OPEC's behavior would have kept the oil price above its competitive level over the long 
run. As a price taker, there would be no implications on the marginal external cost for US oil imports, apart from costs due to short-run volatility. However, being the largest consumer, the United States has monopsony power, which, for instance, is reflected in a slight increase in oil prices when the overall US import demand for oil increases. The higher oil price/expenditure has to be paid for both domestic and imported supplies, resulting in additional externality/costs on wealth transfer out of the United States. The difference between this cost and the market price for an additional unit of imported oil depends on the level of US imports as well as the effect of US demand on the world price of oil. Similarly, if there is a decrease in US demand leading to a slight decrease in the world oil price, it would lead to monopsony benefits due to avoided payments to the exporting countries.

Parry and Darmstadter (2003) estimated the marginal external cost per barrel of US oil imports from monopsony power as a ratio of world price divided by the elasticity of supply of US imports with respect to world price. To estimate this response, those authors assumed import supply elasticities between 0 and 20 and world oil prices of $\$ 15, \$ 25$, and $\$ 35$ per barrel. The response function convex to the origin showed that, at lower import supply elasticities, the premium was very high. For example, when the elasticity is 2 and the world price of oil is $\$ 25$ per barrel, the premium was greater than $\$ 15$ per barrel; whereas when the elasticity took a larger value, the premium fell closer to zero. For an elasticity ranging from 5 to 20 , the estimated premium ranged from $\$ 1.3$ to $\$ 5.0$ per barrel at a world oil price of $\$ 25$ per barrel.

However, as NAS (2009) indicates, the premium resulting from monopsony power reflects the fact that individual consumers per se do not recognize this potential buying power that exists when the entire United States together executes.

A major component of oil dependence cost that is not incorporated into the price of oil is the cost of macroeconomic disruption. As discussed above, macroeconomic disruptions include transfers of US wealth to oil exporters and the impact of cost increases on the economy in terms of loss in economic output, income, and jobs (NAS, 2009). A comparison of estimates across various studies on the costs of oil dependence that include monopsony as well as macroeconomic disruption costs is provided in Table 5. The monopsony cost reflects the cost of importing oil due to the effect of changes in US import demand on the world oil price over the long run. This cost is estimated to range from $\$ 8.9$ per barrel in 2006 to $\$ 12.68$ in 2040. In 2005 dollars, the monopsony cost estimated by Leiby (2008) was $\$ 7.41$ in 2007, and it increased to $\$ 11.79$ in 2015. In contrast, the monopsony cost estimates by the US EPA and NHTSA (2010) were around $\$ 12$ per barrel for the years 2020,2030, and 2040. The monopsony

Table 5. Comparison of estimated cost of oil dependence

\begin{tabular}{|c|c|c|c|c|}
\hline Year & Monopsony (range) & Macroeconomic Disruption & Total Midpoint (range) & Study \\
\hline $\begin{array}{c}2006 \\
(2004 \$ / \text { barrel) }\end{array}$ & $\begin{array}{c}8.9 \\
(2.91-18.40)\end{array}$ & $\begin{array}{c}4.68 \\
(2.18-7.81)\end{array}$ & $\begin{array}{c}13.58 \\
(6.71-23.25)\end{array}$ & Greene and Leiby (2006) \\
\hline $\begin{array}{c}\mathbf{2 0 0 7} \\
(2005 \$ / \text { barrel) }\end{array}$ & $\begin{array}{c}7.41 \\
(2.77-13.11)\end{array}$ & $\begin{array}{c}4.59 \\
(2.10-7.40)\end{array}$ & $\begin{array}{c}12.00 \\
(6.67-17.95)\end{array}$ & Leiby (2008) \\
\hline $\begin{array}{c}2009 \\
(2005 \$ / \text { barrel })\end{array}$ & $\begin{array}{c}9.00 \\
(3.22-16.71)\end{array}$ & $\begin{array}{c}5.45 \\
(2.59-8.69)\end{array}$ & $\begin{array}{c}14.45 \\
(7.82-21.98)\end{array}$ & Leiby (2008) \\
\hline $\begin{array}{c}2015 \\
(2005 \$ / \text { barrel) }\end{array}$ & $\begin{array}{c}11.79 \\
(4.26-21.37)\end{array}$ & $\begin{array}{c}6.70 \\
(3.11-10.67)\end{array}$ & $\begin{array}{c}18.49 \\
(7.82-21.98)\end{array}$ & Leiby (2008) \\
\hline $\begin{array}{c}2020 \\
(2008 \$ / \text { barrel) }\end{array}$ & $\begin{array}{c}12.28 \\
(4.16-23.74)\end{array}$ & $\begin{array}{c}7.39 \\
(3.39-11.92)\end{array}$ & $\begin{array}{c}19.66 \\
(10.27-30.90)\end{array}$ & $\begin{array}{l}\text { US EPA and NHTSA } \\
(2010)\end{array}$ \\
\hline $\begin{array}{c}2030 \\
(2008 \$ / \text { barrel) }\end{array}$ & $\begin{array}{c}12.69 \\
(4.43-23.80)\end{array}$ & $\begin{array}{c}8.54 \\
(4.10-13.60)\end{array}$ & $\begin{array}{c}21.33 \\
(11.30-32.88)\end{array}$ & $\begin{array}{l}\text { US EPA and NHTSA } \\
(2010)\end{array}$ \\
\hline $\begin{array}{c}\mathbf{2 0 4 0} \\
(2008 \$ / \text { barrel) }\end{array}$ & $\begin{array}{c}12.68 \\
(4.41-23.41)\end{array}$ & $\begin{array}{c}8.99 \\
(4.48-14.08)\end{array}$ & $\begin{array}{c}21.67 \\
(11.54-31.10)\end{array}$ & $\begin{array}{l}\text { US EPA and NHTSA } \\
(2010)\end{array}$ \\
\hline
\end{tabular}

Note: Figures in parentheses are based on the lower- and upper-bound elasticities of US GDP to oil price. 
effect implies that if the US imports $10 \mathrm{mbpd}$ of oil at a world price of $\$ 100$ per barrel, it would cost $\$ 1$ billion per day. If US imports drop to $9 \mathrm{mbpd}$ and result in world prices falling to $\$ 98$ per barrel, then the daily cost of oil imports would drop to $\$ 882$ million. The drop in oil price payments by $\$ 118$ million is equivalent to an incremental benefit of $\$ 118$ per barrel of reduced oil imports ( $\$ 118$ million per day/1 million barrels per day) or $\$ 20$ more than the newly decreased oil price of $\$ 98$ per barrel. The import cost premium is represented by this additional \$20 per barrel, which indicates the incremental external benefits to the United States for avoided import costs beyond the price paid by oil purchases.

The macroeconomic disruptions or adjustment costs refer to costs such as the additional cost of imports due to spikes in oil prices in the short run and the costs associated with GDP loss, macroeconomic contraction, and allocative or adjustment losses. As the table indicates, these estimated costs were around $\$ 5.45$ per barrel in 2009 (Leiby, 2008) and could be as high as $\$ 8.99$ per barrel in 2040 (US EPA \& NHTSA, 2010). The total midpoint values are the sum of monopsony costs and the macroeconomic disruption costs. The US EPA and NHTSA (2010) estimate for 2020 indicated that the total energy security premium associated with a reduction in imported oil is $\$ 19.66$ per barrel, which amounts to $\$ 0.47$ per gallon of gasoline. Although the bulk of the oil dependence cost is due to the monopsony cost, Greene et al. (2011) argued that the cost of monopsony power should not be treated as an externality, and taxing oil or imported oil is not an adequate solution to this problem.

\section{Subsidies for Transportation Fuels}

Globally, most transportation fuels are associated with subsidies and/or taxes, along with import tariffs, contributing to social costs and benefits associated with these policy instruments. Not much work has been done on estimating the full extent of subsidies given to fossil fuels. However, Victor (2009) indicated that the total consumption subsidy on fossil fuels in the major 20 non-OECD countries amounted to $\$ 300$ billion. Subsidies are frequently used by governments to achieve social objectives. These include growing markets, leveraging national resources, providing employment, and promoting energy security. However, subsidies (by design) alter market signals/ mechanisms and change producers' and consumers' choices.

IEA (2011a) reported that fossil-fuel subsidies result in market distortions and would lead to an economically inefficient allocation of resources, while the subsidy policies often fail to meet their intended objectives. Although the rationale behind subsidies for fossil fuels is often to alleviate poverty or to promote economic development, they could encourage unintended consequences such as creating wasteful consumption, threatening energy security by increasing imports and decreasing exports, encouraging fuel adulteration and smuggling, discouraging investment in energy infrastructure, distorting markets and creating barriers for clean energy investments, and leading to an increase in $\mathrm{CO}_{2}$ emissions due to greater consumption of fossil fuels.

IEA (2011a) estimates that global fossil fuel subsidies accounted for $\$ 409$ billion in 2010, of which about 48 percent constituted subsidies for crude oil, 30 percent for electricity, and 22 percent for natural gas. Not much research has been done on the full inventory of direct and indirect subsidies related to transportation fuels, particularly fossil fuels and their intended and unintended impacts on energy markets. Accounting for the costs of energy subsidies is essential for assessing the full cost of energy security and externalities.

The US federal government's financial interventions and subsidies provided to the energy sector are reported in Table 6 . The subsidies provided to the energy market more than doubled from $\$ 17.9$ billion in 2007 to $\$ 37.1$ billion in 2010 . The total subsidy is the sum of direct expenditures ( $\$ 14.3$ billion in 2010 ), tax expenditures ( $\$ 16.28$ billion), research and development ( $\$ 4.4$ billion), and other components. The bulk of the energy subsidy in 2010 went for conservation, end use (consumption), and the Low Income Home Energy Assistance Program (LIHEAP) ( $\$ 14.8$ billion in 2010$)$.

One important category that is most relevant here is the "fuels used outside the electricity sector," which constituted about $\$ 10.5$ billion, accounting 


\begin{tabular}{|c|c|c|}
\hline Subsidy and Support Category & FY 2007 & FY 2010 \\
\hline Electricity Related & 7,663 & 11,873 \\
\hline $\begin{array}{l}\text { Fuels and technologies used for } \\
\text { electricity production }\end{array}$ & 6,582 & 10,902 \\
\hline Transmission and distribution & 1,081 & 971 \\
\hline $\begin{array}{l}\text { Fuels Used Outside the } \\
\text { Electricity Sectora }\end{array}$ & 6,246 & 10,448 \\
\hline $\begin{array}{l}\text { Conservation, End Use, and } \\
\text { LIHEAP }\end{array}$ & 3,987 & 14,838 \\
\hline Conservation & 369 & 6,597 \\
\hline End use/other & 1,342 & 3,241 \\
\hline LIHEAP & 2,276 & 5,000 \\
\hline Total & 17,895 & 37,160 \\
\hline \multicolumn{3}{|c|}{$\begin{array}{l}\text { Biomass and biofuels constituted } \$ 4.0 \text { billion (FY 2007) and } \$ 7.6 \text { billion } \\
\text { (FY 2010) of the subsidy. }\end{array}$} \\
\hline \multicolumn{3}{|c|}{ Source: US DOE/EIA (2011b). } \\
\hline
\end{tabular}

for 28 percent of energy subsidies in 2010. About $\$ 7.6$ billion of this subsidy went for supporting biomass and biofuels. Under the Volumetric Ethanol Excise Tax Credit (VEETC), blenders of ethanol with gasoline received a credit of $\$ 0.45$ per gallon $(\$ 0.60$ per gallon for alcohol fuel mixtures [nonethanol], $\$ 0.50$ per gallon of biodiesel, and $\$ 1.00$ per gallon of agri-biodiesel). The VEETC alone constituted $\$ 5.7$ billion in 2010 , which was categorized as a reduction in excise tax revenues. However, the VEETC expired on December 31, 2011. Apart from biofuels, natural gas and petroleum liquids also received significant subsidies, constituting 20.7 percent of fuel-specific subsidies (US DOE/EIA, 2011b). Because the energy subsidies pose many positive and negative externalities, it is important to account for these components while estimating the energy security costs.

\section{National Security Costs of Securing Energy}

The rising cost of imports due to higher oil prices poses a threat to economic as well as national security. The growing dependence on foreign oil also constrains our ability to pursue strategic foreign policy and national security objectives (Deutch, Schlesinger, \& Victor, 2006). Furthermore, greater dependence on imports leads to higher national security costs. The US military has been playing a crucial role in ensuring continued production and transportation of oil, particularly in politically volatile regions with frequent conflicts and insurgency. Former Commander General Wesley Clark urged the United States to achieve energy independence for the sake of national security and financial stability and to avoid conflicts with unfriendly countries with abundant oil (Fehrenbacher, 2008).

As discussed above, OPEC is capable of limiting the supply of oil to countries such as the United States, thus resulting in higher prices. The exercise of OPEC's monopolistic power leads to a slower transition to a substitute (such as alternative fuels) than would be experienced in a competitive market. For alternative fuels to be cost competitive, oil prices must be stable. If OPEC momentarily slashes oil prices by increasing its oil supply, production of alternative fuels would become economically infeasible and could impede the growth of the industry. Because substitutes for oil are largely unavailable, it gives oil producers even more power to increase prices (Tietenberg \& Lewis, 2009). National security concerns are important in terms of OPEC's control over oil production and supply. The most recent National Defense Strategy emphasizes the importance of maintaining access to energy sources (Crane et al., 2009). Many OPEC members are politically unstable countries such as Iran, Iraq, Nigeria, and Libya. Disruptions in supply are a constant possibility and could lead to international conflicts. Vulnerable strategic imports lead to an extra cost not reflected in the price of oil at the pump.

National security is considered a "public good," which is defined as a resource distinguished by nonexclusivity ${ }^{1}$ and indivisibility ${ }^{2}$ (Tietenberg \& Lewis, 2009). If an oil embargo were to occur in the short run, demand would become close to perfectly inelastic, and US consumers would pay virtually any price for oil. It is possible that a sharp reduction in supply or increase in price level could also lead to an economic recession (Crane et al., 2009). Substantial monetary and military investments must be made to protect security of the production and transport of

\footnotetext{
${ }^{1}$ Nonexclusivity implies that no individual can be excluded from using the good, regardless of whether they paid for it.

${ }^{2}$ National security is indivisible because it is a collective good that cannot be bought by an individual.
} 
oil from areas such as the Persian Gulf. Estimates of the financial investments made to secure protection of these sources range from $\$ 13$ billion to $\$ 143$ billion per year (Crane et al., 2009). Even a small portion of this security cost spent on developing alternative fuels would be rewarding in moving toward energy security.

The Southern States Energy Board (2006) estimated that the national security cost of imported oil is about $\$ 300$ billion per year. The RAND Corporation estimated the incremental cost to the annual US defense budget for secured supply and transit of oil to be about $\$ 83$ billion (15 percent of defense budget) (Crane et al., 2009). With the import of 176 billion gallons of liquid petroleum products, the national security cost amounts to an additional $\$ 1.70$ per gallon and may be up to $\$ 3.40$ per gallon at the pump, if it is assumed that all of the national security costs are borne by the half of US imports that come from unfriendly and unreliable sources.

Parry and Darmstadter (2003) argue that because US military expenditures in the Middle East are partly to secure imported oil, these expenditures should be counted toward the total cost of oil import dependency. Several studies on estimating energy security costs do not account for military expenditures, mainly because of the difficulty in assessing the correct portion of military costs that should be attributed to the external costs of oil. Another major reason for not incorporating military spending into the external costs of oil is that it will not vary much with changes in oil imports.

The US Department of Defense's (DoD's) consumption of petroleum and expenditures on petroleum from 1998 to 2010 are depicted in Figure 7. Although oil consumption by US defense constitutes less than 2 percent of total US consumption, it still forms a considerable portion of the defense budget. In 2010, petroleum consumption (left axis in the figure) by US defense was 130 million barrels, which cost about $\$ 13.40$ billion. With record high oil prices in 2008, the petroleum expenditure constituted $\$ 17.9$ billion for the consumption of 132.5 million barrels of oil. This indicates the vulnerability of defense expenditures to oil price shocks. Even a smaller rise

\section{Figure 7. US defense consumption of and expenditure on petroleum}

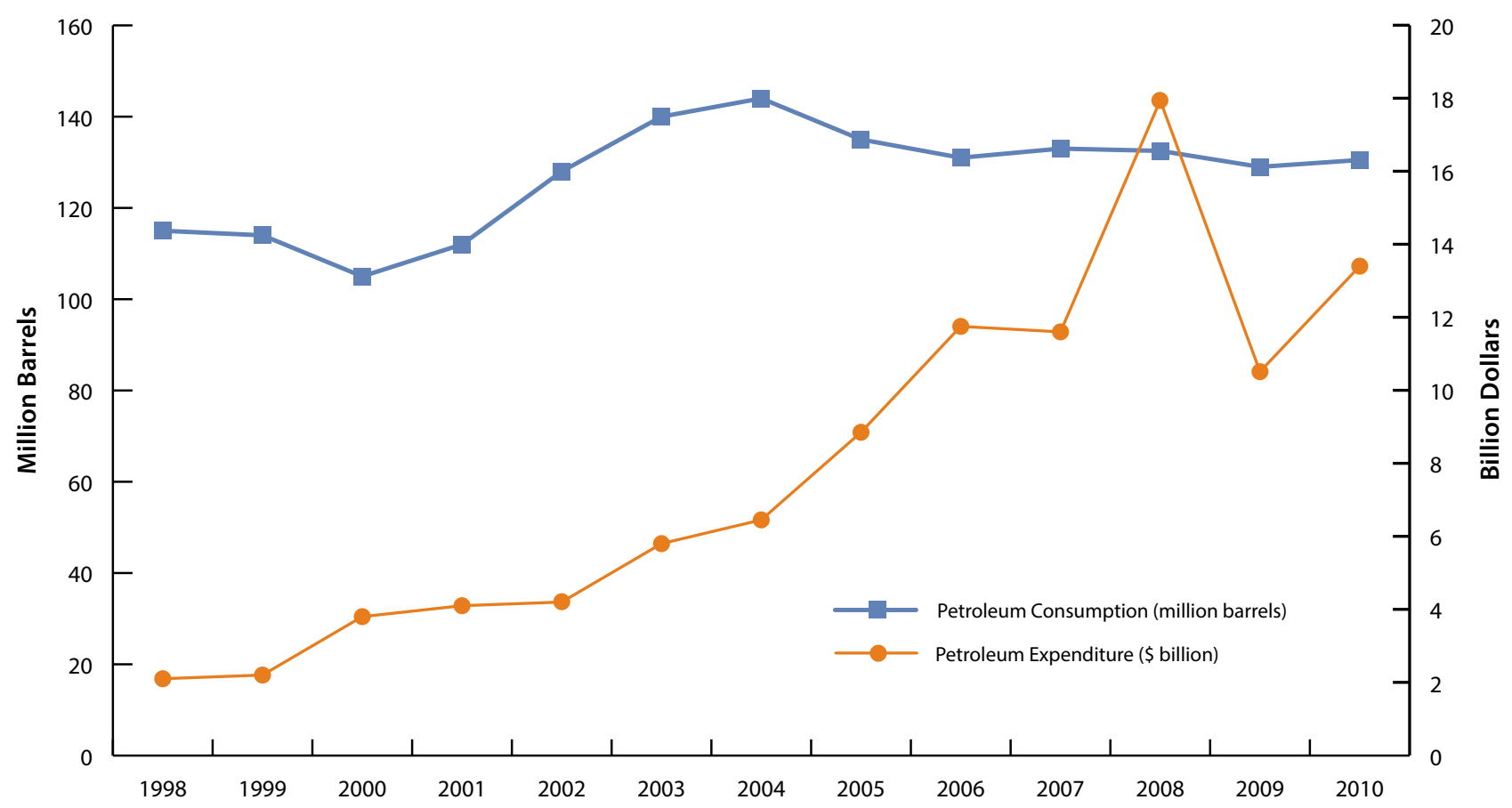

Source: US Defense Logistics Agency. Energy Fact Books (FY 2000 through FY 2011). 
in oil prices considerably affects defense expenditures, which could affect executing strategic missions.

Although it is challenging to assess the military cost of oil dependency, a few attempts have been done in the literature to quantify these costs. Delucchi (2005) estimated that the military cost of oil for 1991 was about $\$ 0.6$ to $\$ 6.8$ billion. Copulos (2006) incorporated several elements of the "hidden cost" of imported oil for estimating the cost of oil dependence. The author indicated that "hidden costs" would include the (a) cost of oil-related defense expenditures, (b) loss of current economic activity due to capital outflow, (c) loss of domestic investment, (d) loss of government revenues, and (e) cost of periodic oil supply disruptions. Copulos argued that when these elements are taken together, they constitute a financial drain that is nearly twice that of total national defense expenditures. Table 7 presents the high cost of imports estimated by Copulos (2006). The current costs, defined as the loss of direct employment that would have occurred as a result of an equal amount of capital being spent in the domestic economy, constituted $\$ 117$ billion in 2006 (a sharp increase from $\$ 37$ billion in 2003, due to higher oil prices). The investment losses include economic activity resulting from the subsequent economic transactions based on an expenditure equivalent of capital in the domestic economy and also the activity resulting from reinvesting the profits from it. The investment losses were estimated to be about $\$ 123$ billion in 2003 and $\$ 394$ billion in 2006. The current costs and investment costs together constitute the total economic cost.

\begin{tabular}{lcc}
\hline \multicolumn{3}{l}{ Table 7. The high cost of oil imports (\$ billions) } \\
\hline Cost Components: & $\mathbf{2 0 0 3}$ & $\mathbf{2 0 0 6}$ \\
\hline Current cost & 36.7 & 117.4 \\
\hline Investment loss & 123.2 & 394.2 \\
\hline Total Economic Cost & 159.9 & 511.6 \\
\hline Gov. revenue losses & 13.4 & 42.9 \\
\hline Total Losses & 173.3 & 554.5 \\
\hline Defense costs & 49.1 & 137.8 \\
\hline Oil shocks & 82.5 & 132.8 \\
\hline Total & 304.9 & 825.1 \\
\hline
\end{tabular}

Source: Copulos (2007).
Furthermore, government revenue losses (local, state, and federal tax revenues) were $\$ 13$ billion in 2003 and reached $\$ 43$ billion in 2006 because of an increase in outlays for the purchase of foreign oil (Table 7). The total losses are the sum of total economic costs and government revenue losses. The defense costs constituted about $\$ 137$ billion during 2006, and the estimates of amortized costs of supply disruptions amounted to $\$ 133$ billon. In all, the total external cost or hidden cost of oil was found to be $\$ 825.1$ billion in 2006, which is nearly twice the DoD's budget in 2006. In other words, Copulos (2007) estimated that the hidden cost is equivalent to $\$ 8.35$ per gallon of gasoline refined from oil imported from the Persian Gulf. Beyond the monetary costs, the author's estimate of employment loss was about 2.24 million jobs in 2006.

If externalities such as national security costs were included in the price of oil, it could boost the US transition to alternative fuels such as biofuels that use domestic resources, create jobs, and retain wealth in the United States. In addition, technologies such as natural gas, hydrogen, electric vehicles (EVs) etc. that could reduce oil imports could help achieve energy security. A related issue concerning national security is how the revenues earned by oil-exporting countries are recycled back to the US economy (Levi, 2010). The revenues could be channeled through purchases of US goods and services, public and private debt, and/or assets. Additional insights on this issue would help gauge the consequences of oil price volatility. Some studies have also indicated that higher oil prices have historically had a contractionary effect on the US economy. In contrast, there is ample evidence that energy prices have contributed to the macroeconomic performance of energy-exporting countries (Barsk \& Kilian, 2004). This issue is pertinent given the current global economic situation and needs to be examined in the scope of net energy-consuming and net energyproducing economies.

\section{Externalities of Energy}

Externalities can be defined as the inefficiencies that arise when some of the benefits accrue to or costs are imposed on individuals who are not directly involved in market agreements. In other words, externalities reflect positive (benefit) and negative 
(cost) implications for the well-being of one agent as a result of activities of another, external to the market mechanism. Although some studies do not treat the cost of oil dependence as an externality (Greene, 2011), several other studies (e.g., Copulos, 2003; NAS, 2009) have treated the external or hidden costs as an externality of oil consumption. In estimating the external costs of oil, Copulos (2003) included these elements: cost of oil-related defense expenditures, the loss of current economic activity because of capital outflow, the loss of domestic investment, the loss of government revenues, and the cost of periodic oil supply disruptions. However, the NAS (2009) study focused more on estimating the environmental externalities. In this section, we focus on assessing the environmental externalities across selected transportation fuels based on economic and LCA models.

\section{Environmental Externalities of Transportation Fuels}

One of the major environmental externalities for transportation fuels is their GHG emissions. Studies have used LCA techniques to measure the GHG externalities of transportation fuels. An LCA technique helps analyze the full impacts of a product by accounting for all stages of its life cycle, both direct and indirect economic and environmental impacts. For instance, the crude oil externality could be calculated starting from crude oil extraction, refining, transportation and distribution, storage, and moving to the final use of refined products in transportation. Alternative transportation fuels have gained momentum in the United States, primarily corn ethanol to date, because they have been envisioned to contribute to energy security by reducing oil imports, improving the balance of trade, and creating more jobs in rural areas. However, using corn ethanol has other economic implications such as the cost of subsidies or tax credits and higher corn prices. In addition, using corn ethanol has environmental impacts such as its impact on land use, water use, and GHG emissions. The existing literature on GHG emissions from various transportation fuels indicates contrasting findings. Some LCA studies have shown net reductions in GHG emissions for certain biofuels relative to fossil fuels, while others argue that biofuels produced on converted land could lead to greater GHG emissions than fossil fuels when fully accounting for emissions from land use change. These findings offer an ample scope to more fully characterize different assumptions and methodologies adopted in estimating these externalities across different transportation fuels.

One of the most widely debated externalities associated with large-scale biofuels production is the consequences on land use. The conversion of land not only releases GHGs, but also leads to degradation of soil and water resources and loss in biodiversity. The nascent literature on biofuels indicates that not much work has been done on these issues in a comprehensive manner across alternative fuels.

On the fossil fuels side, currently about 8,000 tankers are involved in transporting oil and its products across the world (Slingenberg et al., 2009). Although oil spillages due to tanker accidents or at oil wells/ refineries are not frequent, some past incidents have caused profound consequences on the environment and the energy market. Thus, it is important to include these environmental assessments when accounting for the externalities across transportation fuels.

\section{A Review of Environmental Externalities of Fossil Fuels}

This section gives an overview of the externalities associated with different transportation fuels in the literature. Tables A-1 and A-2 in the Appendix give a relative comparison of externalities across 15 different transportation fuels. One of the major environmental externalities associated with energy production and consumption is GHG emissions, which may play a role in climate change. GHG emissions from the transportation sector accounted for approximately 23 percent of anthropogenic GHG emissions worldwide (Kahn et al., 2007). Over the past 10 years, however, transportation emissions have increased more rapidly than emissions from any other energy sector. About 27 percent of total US $\mathrm{CO}_{2}$ emissions are directly attributed to the transportation sector, about twothirds of which come from gasoline and diesel use in motor vehicles (US EPA, 2010). If the current growth in energy use continues, GHG emissions from the transportation sector are expected to increase at an annual rate of 2 percent (Bernstein et al., 2007). 
Gasoline and diesel are presently the main sources of transportation fuels, and their impact on global GHG emissions is substantial. Current prices of these fuel sources do not take into account the significant costs associated with human health and well-being, energy security, and environmental impacts. Costs not included in the price at the gasoline pump are examples of negative externalities. Some alternatives to these traditional fuels discussed here are liquefied petroleum gas (LPG); hydrogen; coal to liquids (CTL); CNG; GTL; EVs; and renewable fuels such as ethanol and biodiesel from traditional crops, dedicated energy crops, crop residues, forest residues, and algae-based biodiesel. In terms of researching environmental impacts of energy alternatives, it is important to assess life-cycle GHG impacts. One issue is that a limited number of studies have been done on both mitigation potential and environmental effects of these alternative energy sources, particularly outside of renewable fuels that were studied for the RFS.

\section{Gasoline}

Oil is a fossil fuel formed from decaying plant and animal matter and blended with sediments of shallow seas and then covered by strata. Under conditions of high temperature and pressure, and over hundreds of millions of years, petroleum is created (Kingston, 2002). Gasoline is refined petroleum with a blend of hydrocarbons (HCs) and contaminants including low levels of sulfur, nitrogen, oxygen, and metals. In addition to emitting GHGs when the fuel is burned, the extraction of this fuel causes international land use change. Extraction and refining procedures have led to some of the worst environmental disasters in history, including the Exxon Valdez spill in 1989 and British Petroleum (BP) oil spill in 2010.

In the Exxon Valdez oil spill, approximately 35,000 seabirds were estimated to have been killed. As of 2007, native wildlife and the natural environment had still not fully recovered from the incident (National Oceanic and Atmospheric Administration [NOAA], 2008). Oil continues to pool directly below the surface of the shoreline and may be released when an animal burrows or a severe weather event occurs (NOAA, 2008). Over 20 years later, the environmental impacts are still felt from the Exxon Valdez spill.
The BP oil explosion in the Gulf of Mexico on April 20, 2010, was a news headline for months following the spill. It is one of the most highly publicized environmental externalities associated with petroleum. The total leak amounted up to 4.9 million barrels, which far exceeded the barrels leaked from the 1989 Exxon Valdez oil spill (Hoch, 2010). As reported by BP, it has spent $\$ 14$ billion on cleanup and set aside $\$ 20$ billion for economic claims and restoration work. In terms of overall assessment of environmental impacts, it will take years to completely understand the extent of the damage. Such oil spills could lead to mortality and long-term chronic effects on endangered birds, turtles, fish, and entire ecosystems.

Gasoline is also associated with increased levels of water pollution due to leakage from gas stations and emissions from the use of internal combustion engines. Other significant environmental impacts are associated with petroleum's drilling and extraction processes. Water consumption in the production process varies significantly depending on several factors such as the age of the well and the degree to which produced water is recycled and reused. Oil wells produce high volumes of highly saline water called produced water. On average, approximately 8 gallons of water are required per gallon of crude oil recovered, and about 1.5 gallons of water are necessary to process a gallon of crude ( $\mathrm{Wu}, \mathrm{Mintz}$, Wang, \& Arora, 2009). Historically, disposal practices have been a major concern because of the contaminants that enter the water system. The US Geological Survey (USGS) (2011) is researching the level of contaminants to determine the environmental impacts.

Apart from emitting $\mathrm{CO}_{2}$, methane $\left(\mathrm{CH}_{4}\right)$, and nitrous oxides $\left(\mathrm{N}_{2} \mathrm{O}\right)$, vehicles that use gasoline as their fuel source typically have more emissions of criteria pollutants than some of the alternatives, especially carbon monoxide (CO), volatile organic compounds (VOCs), and nitrogen oxides $\left(\mathrm{NO}_{\mathrm{x}}\right)(\mathrm{Wu}$, Wang, Sharer, \& Rousseau, 2006). US EPA/OTAQ (2011) estimated that $\mathrm{CO}_{2}$ emissions from burning a gallon of gasoline total about 8,887 grams, and emissions from burning a gallon of diesel total 10,180 grams. Furthermore, the study also estimated that a typical passenger vehicle with a fuel economy of 21 
miles per gallon that drives approximately 12,000 miles per year emits about 5.1 tons of $\mathrm{CO}_{2}$ per year. As reported by the US Bureau of Transportation Statistics (2012), the United States had about 250 million registered passenger vehicles in 2010 .

\section{Diesel}

Diesel is the second traditional transportation fuel source. It powers mostly the commercial goods transportation in the United States (Lloyd \& Cackette, 2001). Diesel engines have 35 percent greater fuel economy than traditional gasoline engines (Bernstein et al., 2007). Although diesel fuels contain higher carbon content than gasoline, a diesel engine is more efficient and has lower $\mathrm{CO}_{2}$ emissions per mile than a gasoline engine (MacLean \& Lave, 2003). However, these engines still result in major emissions of GHGs as well as particulate matter $(\mathrm{PM}), \mathrm{NO}_{\mathrm{x}}$, and $\mathrm{HCs}$ (Lloyd \& Cackette, 2001). Apart from the general environmental impacts of diesel, including GHG emissions and water and soil pollution, diesel PM could alter cloud cover and rainfall patterns, leading to changes in the albedo (reflective coefficient) of the earth-atmospheric system. It has been suggested that the extent to which this modification occurs could effectively offset diesel's $\mathrm{CO}_{2}$ advantage over gasoline (Lloyd \& Cackette, 2001).

\section{Liquefied Petroleum Gas (LPG)}

LPG comprises HC-based gases derived from both crude oil and/or natural gas. LPG is formed naturally along with petroleum and natural gases $\left(\mathrm{CH}_{4}\right)$. Because it is a fossil fuel, negative environmental externalities are associated with the extraction process. LPG comprises either propane, butane, or a mix of both (US DOE/Office of Energy Efficiency and Renewable Energy [EERE], 2003). Only 0.1 percent of LPG was used for transportation in 2005, but it is becoming more popular as a promising alternative fuel. Gasoline has a higher energy input than LPG by approximately 26 percent. LPG vehicles release about a third fewer reactive organic gases than traditional gasoline vehicles (US DOE/EERE, 2003). Although it is cleaner than gasoline, LPG still produces emissions from combustion, including $\mathrm{PM}$, sulfur dioxide $\left(\mathrm{SO}_{2}\right), \mathrm{NO}_{\mathrm{x}}, \mathrm{N}_{2} \mathrm{O}, \mathrm{CO}, \mathrm{CO}_{2}, \mathrm{CH}_{4}$, and nonmethane total organic carbon.

\section{Hydrogen}

Hydrogen is mostly produced by natural gas reforming, although it can also be produced from coal through a gasification process and electrolysis. In the case of coal-based hydrogen, coal is first reacted with steam and oxygen under high temperature and pressure conditions to make a syngas, which is made up of hydrogen and CO (US DOE, 2010). The mixture is cleaned and reacted with steam to produce greater quantities of hydrogen and $\mathrm{CO}_{2}$. Hydrogen is then separated and $\mathrm{CO}_{2}$ may be captured and sequestered. It is also possible for other pollutants like $\mathrm{SO}_{\mathrm{X}}, \mathrm{NO}_{\mathrm{X}}$, mercury, and particulates to be captured so they do not enter the atmosphere. Burning of hydrogen results in only water vapor, and it does not emit any $\mathrm{CO}_{2}$ or $\mathrm{CO}$ gases. Although hydrogen is more energy dense on a mass basis $(61,000$ Btus per pound compared with 20,900 Btus per pound for gasoline), it is much less energy dense on a volume basis ( 1 gallon of liquid hydrogen yields only 27.6 percent of that energy that a gallon of gasoline yields). Because of this major limitation, hydrogen is not considered a promising alternative transportation fuel for the near future.

\section{Coals to Liquids (CTL)}

Because of energy security concerns, CTL could be a possible source of domestic transportation fuels. Over 200 billion short tons of demonstrated coal reserves are accessible for mining purposes (Brathwaite, Horst, \& Jacobucci, 2010). Both lignite and bituminous coal can be used for converting to synthetic diesel using the Fischer-Tropsch process, which is a series of chemical reactions that convert $\mathrm{CO}$ and hydrogen mixtures into liquid HCs. The result is the production of a petroleum substitute.

Although there is a large supply of coal in the United States, CTL fuels have major externalities, including the environmental impacts associated with the extraction and refining processes. Using CTL in automobiles would also generate emissions leading to negative environmental externalities. The fuel contains the same waste characteristics of traditional diesel fuels (Brathwaite et al., 2010).

An LCA conducted by Jaramillo, Samaras, Wakeley, and Meisterling (2009) on CTL fuels included two 
possible future scenarios: high emissions (no carbon capture and storage [CCS], high emission electricity) and low emissions (electricity from low emission sources, with CCS). In the former scenario, overall GHG vehicle emissions could be increased by up to 90 percent when compared with current petroleumbased gasoline. In the low-emissions scenario, CTL would still increase emissions by over 5 percent. The authors pointed out that the low-emissions scenario is not very realistic, and overall, the coal refining process is much less efficient and more complex than the oil conversion process (Brathwaite et al., 2010; MacLean \& Lave, 2003). In fact, it takes 100 pounds of coal to produce 1 gallon of gasoline. It takes 1.5 gallons (about 10 pounds) of oil to produce 1 gallon of gasoline (Brathwaite et al., 2010). The resource inputs necessary should be taken into account when assessing the overall efficiency of CTL.

Coal mining could also affect water quality through mine drainage, which is formed when iron sulfides are exposed to and react with air and water. The resulting formations are sulfuric acid and dissolved iron. The iron can precipitate to form sediments along the stream beds. Acid runoff dissolves heavy metals including copper, lead, and mercury into both ground and surface water. Acidic and metallic drainage from coal mines can lead to substantial degradation of aquatic resources. Issues that arise from mine drainage include contamination of drinking water, disruption of growth and reproduction of plants and animals in aquatic systems, and corrosion of bridges and other infrastructure. In West Virginia, USGS (2011) has estimated that correcting mine drainage issues will cost around $\$ 5$ to $\$ 15$ billion.

At least partially because of these conversion statistics and the highly capital-intensive nature of a project, no CTL plants have been built in the United States (Jaramillo et al., 2009). Although the US coal supply is large, an analysis of the transition from gasoline to coal has not been researched (Brathwaite et al., 2010); thus, the true magnitude of environmental externalities has not been established.

\section{Compressed Natural Gas (CNG)}

Natural gas mainly comprises $\mathrm{CH}_{4}$ and can be converted to $\mathrm{CNG}$ and used in vehicle transportation (Bernstein et al., 2007). CNG has small amounts of propane, butanes, and pentanes with very low $\mathrm{CO}_{2}$ emissions at the tailpipe (MacLean \& Lave, 2003). In terms of the entire fuel cycle, CNG generates the lowest $\mathrm{CO}_{2}$ emissions per vehicle mile travelled when compared with gasoline, diesel, and LPG (US DOE/ EIA, 1996). Overall, CNG has lower ozone-forming potential than gasoline and burns more cleanly than diesel or gasoline (MacLean \& Lave, 2003). Because natural gas is abundantly available in the United States, it can significantly lower oil imports, contributing toward energy security. Environmental impacts of natural gas production should be assessed in terms of extraction processes and emissions of $\mathrm{CH}_{4}$ when the fuel is combusted. As of 2009, there were only 114,000 vehicles, mostly buses, that run on CNG. Currently, the United States ranks 17th in using CNG vehicles, constituting less than 1 percent of the world CNG vehicle fleet. Overall, CNG is expected to be the fastest growing alternative fuel in the United States.

\section{Gas to Liquids (GTL)}

GTL technologies use methane-rich feedstock such as natural gas and LNG to produce fuels such as diesel. A conventional GTL plant can produce about 62 percent diesel, 35 percent gasoline, and 3 percent propane. Pieprzyk, Kortluke, and Hilje (2009) report that GTL, which uses unconventional natural gas in the United States such as tight gas, shale gas, and coal bed methane, results in a 33 percent drop in the GHG balance compared with conventional petroleum. Because of the abundant natural gas reserves in the United States, GTL is emerging as an attractive alternative in moving toward energy security. Also, GTL is sulfur free, with significantly lower $\mathrm{NO}_{\mathrm{x}}$ and $\mathrm{PM}$ emissions compared with conventional petroleum products (Clark, Stephenson, $\&$ Wardle, 2009). As Five Winds International (2004) reports, GTL systems are neutral in their GHG impact compared with the refinery system, and they have the potential to contribute fewer GHGs than conventional diesel. However, like CTL, although GTL production is technically matured, it is highly capital intensive, and the expensive raw materials have hindered its expansion (Pieprzyk et al., 2009). 


\section{Liquefied Natural Gas (LNG)}

LNG is CNG that has been reduced in temperature. Liquefaction, or the process used to condense the gas, uses refrigeration and compression. It consumes about a tenth of the energy content of natural gas (MacLean \& Lave, 2003). The liquefaction and storage processes require expensive equipment. When compared with CNG, the volume of LNG is reduced by a factor of 600; thus, transporting it is more economically feasible. The process of liquefaction removes $\mathrm{O}_{2}, \mathrm{CO}_{2}$, sulfur, and water, resulting in nearly pure $\mathrm{CH}_{4}$. LNG is used extensively in residential heating and in electric power generation, but the use of LNG for transportation is in its infancy. Major concerns about using LNG in automobiles include vapor boil-off from small storage tanks and heat transfer (MacLean \& Lave, 2003). Negative environmental impacts would occur in the event of natural gas spills and could affect water quality and aquatic life if the spill occurs in water and could lead to fire (Hightower et al., 2004).

The continental United States has a large natural gas system for distribution, which is able to quickly and efficiently distribute natural gas throughout the country. Thousands of delivery, receipt, and interconnection points are included in the system. Hundreds of storage facilities and over 50 points for importing and exporting the gas are also already constructed. Some CNG fueling stations do exist, but more would certainly be necessary if the fuel became a major alternative (US EPA/OTAQ, 2002). However, fewer fueling stations exist for LNG, and most users have their own infrastructure dedicated to their vehicles.

\section{Oil Shale}

Oil shale is fine-grained sedimentary rock containing large quantities of kerogen that can be converted into liquid and gaseous HCs, including petroleum liquids, natural gas liquids, and methane. Oil shale is converted to HCs through a heating process without oxygen. Underground mining and in situ processes have been used in the oil production process. Waste products include spent shale and large quantities of water (US DOE, 2010). It is possible that water resources may become of greater concern as climate change continues and human consumption may conflict with water usage from the oil shale refining process.

The in situ process mines rock from the bottom of the oil shale formation and then uses explosives to fragment the shale into smaller pieces (US DOE, 2010). Underground fires are then set to liquefy shale. However, low yields of petroleum have been produced from this technique, and additional environmental issues have arisen. Shifting of the surface lands has become an issue.

Both of these processes can lead to groundwater contamination by pyrolized oil as well as other toxics and metals (US DOE, 2010). One such process, called Shell in situ conversion process, heats the shale for 2 years using electricity. Electricity consumed during this process alone would generate substantial emissions. It is estimated that the final oil product has 1.2 to 1.6 times the total energy output of the overall primary inputs to the process. The overall emissions during the fuel cycle are up to 47 percent larger than conventional fuel sources (Brandt, 2008).

\section{A Review of Environmental Externalities of Renewable Fuels}

Renewable fuels are produced from renewable energy feedstocks. These fuels include biodiesel and ethanol. Advanced biofuels such as dedicated energy crops and forest and crop residues are also renewable fuels. Many techniques such as fermentation of starch/sugars, esterification of vegetable oil, and thermochemical and biochemical conversion of cellulose are in practice for converting feedstocks into biofuels (Bernstein et al., 2007). Biofuels have gained momentum in recent years as a result of the implementation of the RFS. In 2005, US EPA collaborated with refiners, renewable fuel producers, and stakeholders to create the RFS. The original RFS was crafted under the Energy Policy Act (EPAct) of 2005 and created the first US renewable fuel volume mandate (US EPA/OTAQ, 2012). The first RFS program, called RFS1, mandated 7.5 billion gallons of renewable fuel to be mixed with gasoline by 2012 . The EISA of 2007 expanded the program and renamed it RFS2. Key changes included increasing the annual volume requirements to 36 billion gallons by 2022 with a cap on corn ethanol at 15 billion gallons and the remainder coming from advanced biofuels and 
cellulosic fuels, as well as adding a requirement to apply life-cycle GHG performance threshold standards (US EPA/OTAQ, 2012). The life-cycle standards were established to ensure that renewable fuels emit lower emissions levels than the petroleum fuels they replace. Because of implementing these standards, more research has been conducted on these fuels than on any other alternative transportation fuel.

It is necessary to assess trade-offs associated with different renewable fuels to fully understand the impacts of each. Some biofuels have the potential to reduce GHGs that lead to anthropogenic climate change, although they also have many environmental impacts that need to be taken into account. Crop production for biofuels has implications on water and soil quality, biodiversity, and the landscape (Lankoski \& Ollikainen, 2010). Another externality is that bioenergy crops have the potential to become invasive species.

Enhanced production of biofuels can also be detrimental to biodiversity of agricultural landscapes. Biodiversity is defined as "species richness and estimated as number of species of plants, animals and microorganisms per unit area" (Sala, Sax, \& Leslie 2009 , p. 127). Biodiversity may be negatively affected as a result of habitat loss, greater numbers of invasive species, and pollution due to greater fertilizer and herbicide application from increased land conversion to produce biofuels feedstock. Conversely, positive externalities may also be expected because some biofuels may lower global carbon emissions (Sala et al., 2009).

Habitat loss is another negative impact of land conversion for crop production (Lankoski \& Ollikainen, 2010). Other externalities of biofuels production include emissions of coarse particulate matter $\left(\mathrm{PM}_{10}\right)$, fine particulate matter $\left(\mathrm{PM}_{2.5}\right)$, and VOCs (Kusiima \& Powers, 2010). As biofuel production evolves, it is expected that emissions from $\mathrm{CO}_{2}$ currently stored in soils and forests will be released when land is converted and the biomass is burned while converting forest or pasture lands to cropland.

In a recent study, researchers assessed a variety of biofuels, including cellulosic feedstock, and found that total external costs were highest for corn-based ethanol (Kusiima \& Powers, 2010). The emissions that have the greatest effect are those from fossil fuel combustion for heat and electricity used in chemical, feedstock, and ethanol production. For crops whose operations are more actively managed and therefore nitrogen intensive, returns on investment are higher per land parcel. However, there is also an increase in negative environmental externalities. Kusiima and Powers (2010) reported that the choice that had the lowest external costs was the use of forest residues because they are not as actively managed as dedicated energy crops and, therefore, are not likely to have higher levels of nitrogen runoff from fertilizer application.

Conflicting findings of biofuels analyses lead to greater uncertainty about the externalities associated with the production of these alternative fuels. According to the results of a study conducted in Finland, the benefits of the production of biofuel do not exceed the environmental costs (Lankoski \& Ollikainen, 2010). This study claims that current policies in the United States and EU lead to negative overall impacts on the environment, with the exception of biofuels produced from rapeseed and reed canary grass because they have their lower herbicide runoff and biodiversity benefits. For biofuels to become desirable, researchers argue that it is necessary to transfer to no-till cultivation, heighten attention, protect water resources, and produce biofuel more efficiently (Lankoski \& Ollikainen, 2010).

Conversely, another study determined that both corn-based ethanol and biodiesel from soybeans have positive impacts on the environment. Cornbased ethanol reduces GHGs by about 12 percent compared with gasoline but increases environmental impacts, leading to fewer overall benefits. The study found that biodiesel GHGs are reduced by 41 percent when compared with diesel and that biodiesel lowers major air pollutants and has fewer impacts on environmental health through the release of pesticides (Hill, Nelson, Tilman, Polasky, \& Tiffany, 2006). However, both are considered to be better than gasoline or diesel fuels in terms of environmental impacts (Hill et al., 2006). 


\section{Biodiesel}

Biodiesel made from any organic oil source was used as a diesel alternative in the early twentieth century (Campbell, 2008). Different feedstocks such as waste oil, animal fats, jatropha, rapeseed, palm oil, soybeans, and other oilseed crops are currently being used to convert to biodiesel. Substitution of biodiesel for diesel leads to reduced emissions levels of sulfur, soot, unburned $\mathrm{HC}$, and polycyclic aromatic HCs (Campbell, 2008). However, biodiesel does lead to increased $\mathrm{NO}_{\mathrm{x}}$ emissions when compared with traditional diesel; the production of the fuel also generates glycerin by-products and wastewater. Crops grown in the United States for the production of biodiesel, such as soybeans, have substantial chemical inputs, such as nitrogen $(\mathrm{N})$, phosphorous $(\mathrm{P})$, and pesticides, which lead to negative environmental impacts through runoff to other habitats as well as aquifers (Hill et al., 2006). In addition, soybean oil has higher value as a food than the biodiesel it could produce.

Biodiesel derived from algae is another source of biodiesel. The most common algae used in this process are aquatic unicellular green algae, characterized by high growth rates and high population densities. Under proper conditions, algae are able to double their mass in less than a day. Algae can also contain high lipid oils, greater than 50 percent (Campbell, 2008). The lipids are the important component in the process and can yield a much higher oil percentage on a weight basis than sources such as soybeans (19 percent) and rapeseed oil (37 percent). The inputs required to produce algae are $\mathrm{CO}_{2}$, light for photosynthesis, water, and space (Campbell, 2008). It is necessary for high levels of $\mathrm{CO}_{2}$ to be provided to maximize growth. Although significant amounts of water are necessary, they are able to be grown in wastewater sources, such as "coproduced water" from oil, natural gas, coal-bed methane wells, other wastewater from industrial sources, or saline water (Campbell, 2008; Ferrell \& Sarisky-Reed, 2010).

Two main types of systems exist for the production of biodiesel from algae: open race-way ponds and bioreactors. Open race-way ponds are relatively simple; they use the sun as the primary energy source. But the race-way system has limitations of low algae densities, water evaporation, and a high land footprint. In contrast, the bioreactor method, although expensive to build, is preferred for scientific research because it allows for a controlled environment to maximize production (Campbell, 2008). It is likely that these ponds would need to be drained and refilled because of contamination from outside sources as well as evaporation. If saline water is used, it is also likely that treatment would be necessary after use because of high salt content effluent or solid by-products. Salt buildup could have negative environmental impacts and would require additional energy and financial resources to manage (Ferrell \& Sarisky-Reed, 2010). If bioreactors are used, less water would be required, but the growth system is substantially more expensive. Bioreactors may be located on top of flues at industrial power plants, cement plants, and petroleum and natural gas processing plants. The algae in the reactors would use the $\mathrm{CO}_{2}$ in the flue gas to aid in algal growth (Ferrell \& Sarisky-Reed, 2010). Algae is still an emerging renewable fuel, which does not actually sequester carbon; rather, it provides carbon capture and reuse in the form of algae-based fuels. Technological feasibility is the major issue and calls for more research and development.

\section{Sugar- or Starch-Based Ethanol}

Ethanol is produced through a fermentation process of sugars in plants such as corn, forest residue, and switchgrass. Currently, ethanol can be blended with gasoline, or the fuel can be used on its own (Bernstein et al., 2007). In the United States, ethanol is typically blended with gasoline, called E10 because it contains 10 percent ethanol and 90 percent gasoline. It is also possible for mixtures to be up to 85 percent ethanol and 15 percent gasoline (E85) in the United States.

A variety of environmental emissions should be considered when assessing ethanol's externalities: GHGs such as $\mathrm{CO}_{2}, \mathrm{~N}_{2} \mathrm{O}$, and $\mathrm{CH}_{4}$ that contribute to climate change; the potential loss of biodiversity; and acidification from $\mathrm{SO}_{\mathrm{x}}$ (Kusiima \& Powers, 2010). If bioenergy crops are fertilized, eutrophication, or the addition of nutrients to a water body that leads to oxygen depletion, results in a plethora of environmental impacts. Eutrophication from nitrogen runoff leads to negative impacts on fisheries, 
fish poisonings due to algal blooms, reductions in biodiversity, and other water quality effects (Kusiima \& Powers, 2010). Soil erosion from the growth of biofuels leads to degraded farmland and negative offsite impacts such as damaging water quality.

\section{Cellulosic Ethanol From Dedicated Energy Crops}

Dedicated energy crops are those grown expressly for their ability to generate energy. Switchgrass, hybrid poplar, hybrid willows, and miscanthus are examples of energy crops. One major advantage is that some of these crops grow quickly and are perennial in nature. Directly after harvesting, they are able to regenerate themselves, leading to multiple harvests with a 7- to 12-year replanting period. Currently, these crops are not widely grown because they have no market, so growers have no assured price for their crops. However, as the alternative energy market develops, these crops may become more prevalent.

\section{Forest Residues}

Forest residues are by-products of forestry processes. Forest residues help protect the soil, maintain biodiversity and water quality through sediment control, and sequester carbon. Some of these ecosystem services may be reduced if forest residues are removed at unsustainable rates. But removing forest residues in a sustainable manner could improve forest health and at the same time reduce the risk of catastrophic wildfires. In addition, the negative environmental effects of using forest residues are significantly lower than the effects of using other sources of biofuels (Department of Trade and Industry, 2004).

\section{Crop Residue}

Crop residue is leftover material after crops have been harvested in an agricultural field, such as stalks, leaves, and stems. US DOE (2011) estimated that under a baseline scenario (national average corn yield at 1 percent annual growth resulting in 200 bushels/acre in 2030), at a lower price of $\$ 45 /$ dry ton, the supply of crop residues would rise from 25 million dry tons in 2012 to more than 80 million tons in 2030. Under a high-price scenario ( $\$ 60 /$ dry ton), the supply of crop residues was estimated to rise from 110 million tons in 2012 to about 180 million tons in 2030. The study also estimated the supply of crop residue under a high-yield scenario (double the current annual corn yield growth rate to reach 265 bushels/acre in 2030) to reach between 240 and 320 million tons by 2030 under the low- and high-price cases, respectively. Crop residue provides important ecosystem services, such as protecting the quality of soil from water and wind erosion. Residue cover reduces evaporation from the surface of the soil leading to increased drought protection (Andrews, 2006). Removal of these residues for fuel purposes should be done in a sustainable manner to avoid negative environmental externalities. Based on an LCA, US EPA/OTAQ (2012) estimated that although corn grain-based ethanol, on average, would reduce GHG emissions by 21 percent relative to gasoline, corn stover ethanol could reduce GHG emissions by 129 percent.

\section{Electric Vehicles (EVs)}

Purely EVs gain energy from electricity, and batteries with high energy density for greater storage capacity are needed. Some EVs are marketed as "zero-emission vehicles." However, they are battery powered and the electricity source to charge batteries is important to consider. Upstream emissions can be significant depending on the fuel source used to make electricity (MacLean \& Lave, 2003; Elgowainy, Burnham, Wang, Molburg, \& Rousseau, 2009). Furthermore, nearly all materials that make up a battery are toxic heavy metals. The extraction, smelting, production, and disposal processes all lead to significant negative environmental externalities (MacLean \& Lave, 2003). In general, three kinds of batteries are used in hybrid vehicles: lead-acid, nickel metal hydride (NiMH), and lithium-ion (Bernstein et al., 2007; Anair \& Mahmassani, 2012). Although the most commonly used NiMH batteries are less toxic, they are carcinogenic.

Using a life-cycle approach, Elliott (2012) estimated that hybrid-electric vehicles (HEVs) produce about 23 percent less emissions than internal combustion engine vehicles. However, the study also revealed that HEVs are cost competitive only if gasoline prices continue to be high enough to influence consumer preferences for HEVs. Anair and Mahmassani (2012) reported that over the lifetime of an $\mathrm{EV}$, more than 6,000 gallons of gasoline can be saved, contributing 
significantly to the nation's energy security. However, because nearly 50 percent of electricity produced in the United States comes from coal, to obtain the greatest GHG emissions benefit from EVs, it is important to improve the electricity grid and source electricity from cleaner and renewable feedstock.

\section{Life-Cycle Assessment (LCA)}

LCA models evaluate a product at all stages of its life. The LCA approach helps assess the environmental impacts of transportation fuels in a comprehensive way. Several LCA models exist for assessing transportation fuels, but they vary widely in terms of assumptions, coverage of fuels, and parameter values used, for example. We reviewed several LCA models, keeping in mind the transportation fuels that we have selected in this study (Table 8 ).

We reviewed the following models: the Greenhouse Gases Regulated Emissions and Energy Use in Transportation (GREET); ERG Biofuels Analysis Meta-Model (EBAMM); Alternative Liquid Fuels Simulation Model (AltSim); Biofuel Energy Systems Simulator (BESS); GaBi, which includes LCA for sustainable product and process development; and System for Integrated Environmental Assessment of Products (SimaPro). Based on the depth of coverage of feedstock and fuel pathways, we selected the GREET model for this study. This model, developed by Argonne National Laboratory (ANL) (2009), assesses and compares GHG emissions across different transportation fuels.

\section{Application of the GREET Model}

GREET is a fuel-cycle analysis or well-to-wheel analysis model that includes the feedstock, fuel, and vehicle operation stages. GREET offers a number of key advantages over other models:

- A full version of GREET is free and publicly available.

- The model is capable of generating emission scores for North American regions for target years until 2020.

- It covers more than 100 fuel pathways of transportation fuels, includes more than 75 vehicle/fuel systems, and tracks at least eight types of emissions (Figure 8).

\section{Figure 8. Fuel pathways in the GREET model}

\begin{tabular}{|ll}
\hline Petroleum & \\
\hline - Conventional & Gasoline \\
- Oil Sands & Diesel \\
& - Liquefied Petroleum Gas \\
& - Naphtha \\
& - Residual Oil \\
- Coal & Hydrogen \\
& - Fischer-Tropsch Diesel \\
& - Methanol \\
& - Dimethyl Ether
\end{tabular}

\section{Natural Gas}

- North American

- Non-North American

- Compressed Natural Gas

- Liquefied Natural Gas

- Liquefied Petroleum Gas

- Methanol

- Dimethyl Ether

- Fischer-Tropsch Diesel

- Fischer-Tropsch Naphtha

- Hydrogen

Renewable Natural Gas

- Landfill Gas - Compressed Natural Gas

- Liquefied Natural Gas

- Methanol

- Dimethyl Ether

- Fischer-Tropsch Diesel

- Fischer-Tropsch Naphtha

$\begin{array}{ll}\text { - Corn } & \begin{array}{l}\cdot \text { Ethanol } \\ \cdot \text { Butanol } \\ \text { - Sugarcan }\end{array} \\ \text { - Sthanol } \\ \text { - Soybeans } & \begin{array}{l}\cdot \text { Biodiesel } \\ \cdot \text { Renewable Diesel }\end{array}\end{array}$

Cellulosic Biomass

- Switchgrass

- Fast-Growing Trees

- Ethanol

- Crop Residues

- Hydrogen

- Forest Residues

- Methanol

- Dimethyl Ether

- Fischer-Tropsch Diesel

- Residual Oil

- Coal

- Electricity

- Natural Gas

- Nuclear Energy

- Biomass

- Other Renewables

- Coke Oven Gas

- Petroleum Coke

- Nuclear Energy

Source: ANL (2009). 
- It offers significant control over input parameters, helps in modifying the model to user needs, and uses inputs sourced mainly from stakeholders and other simulation models.

- The graphical user interface provides capabilities to perform stochastic simulation to address uncertainties with respect to GREET parameters.

The GREET model provides estimates for GHG emissions, energy, fertilizer, and pesticide/chemical use data associated with an LCA of ethanol. The GHGs included in the model are $\mathrm{CO}_{2}, \mathrm{CH}_{4}, \mathrm{SO}_{4}$, $\mathrm{N}_{2} \mathrm{O}, \mathrm{NO}_{\mathrm{X}}, \mathrm{PM}_{2.5}, \mathrm{PM}_{10}$, and VOC emissions from direct and upstream sources. The GREET model allows for comparison of the emissions and energy sources of a variety of alternative feedstocks (Table 8). The model, however, does not attempt to monetize the external costs of these emissions. For this study, we assigned estimates of the social cost of GHG emissions and the cost of degraded air quality from other regulated emissions reported in GREET.

Table 8. Transportation fuels discussed in this study

\begin{tabular}{|l|l|}
\hline $\begin{array}{l}\text { Fossil Fuels } \\
\text { Based }\end{array}$ & $\begin{array}{l}\text { Ethanol Produced from } \\
\text { Alternative Feedstocks }\end{array}$ \\
\hline - Gasoline & - Corn and other grains \\
- Diesel & - Sugarcane \\
- LPG & - Switchgrass \\
- Hydrogen & - Hybrid poplar \\
- CTL & - Corn stover \\
- CNG & - Forest residues \\
- LNG & \\
- GTL & \\
\hline Oil shale & \\
\hline $\begin{array}{l}\text { Biodiesel from } \\
\text { Vegetable Oils }\end{array}$ & Other \\
\hline - Soybeans & Electric vehicles \\
\hline
\end{tabular}

For valuation of the effects of GHG emissions, we used the estimates of the social cost of carbon (SCC) developed for US regulatory impact analyses (Interagency Working Group on Social Cost of Carbon [IWGSCC], 2010). These estimates are based on multiple projections of the impact of climate change on global economic output and are sensitive to the time frame of analysis and discount rate. We applied the IWGSCC's social cost estimate of \$21.4 per ton of $\mathrm{CO}_{2}$ e for 2010 with a 3 percent discount rate (Table 9). We selected the SCC of $\$ 21.4$ because it is called the "central number" (with the range of $\$ 5$ and $\$ 65$ ) because it has been used in the regulatory impact analyses for US DOT/EPA rules imposing CAFE standards and US DOE regulations of energy efficiency standards (Bell \& Callan, 2011). ${ }^{3}$

Table 9. Social cost of $\mathrm{CO}_{2} \mathrm{e}$ in 2010-2050 (in 2007\$)

\begin{tabular}{lcccc}
$\begin{array}{l}\text { Discount Rate } \\
\text { Year }\end{array}$ & $\begin{array}{c}\mathbf{5 \%} \\
\text { Average }\end{array}$ & $\begin{array}{c}\mathbf{3 \%} \\
\text { Average }\end{array}$ & $\begin{array}{c}\mathbf{2 . 5 0 \%} \\
\text { Average }\end{array}$ & $\begin{array}{c}\mathbf{3} \% \\
\text { 95th Percentile }\end{array}$ \\
\hline 2010 & 4.7 & 21.4 & 35.1 & 64.9 \\
\hline 2015 & 5.7 & 23.8 & 38.4 & 72.8 \\
\hline 2020 & 6.8 & 26.3 & 41.7 & 80.7 \\
\hline 2025 & 8.2 & 29.6 & 45.9 & 90.4 \\
\hline 2030 & 9.7 & 32.8 & 50.0 & 100.0 \\
\hline 2035 & 11.2 & 36.0 & 54.2 & 109.7 \\
\hline 2040 & 12.7 & 39.2 & 58.4 & 119.3 \\
\hline 2045 & 14.2 & 42.1 & 61.7 & 127.8 \\
\hline 2050 & 15.7 & 44.9 & 65.0 & 136.2 \\
\hline
\end{tabular}

Source: IWGSCC (2010).

\section{Application of Air Pollution Emission Experiments and} Policy (APEEP) Model

To estimate the cost of degraded air quality from the non-GHG emissions reported in GREET, we used the estimates generated by the APEEP analysis model (Muller \& Mendelsohn, 2006). The APEEP analysis model is an integrated assessment model that connects emissions of air pollution through air quality modeling to exposure, physical effects, and monetary damages. The model calculates the marginal damage of emissions for about 10,000 distinct sources of air pollution for six pollutants: ammonia $\left(\mathrm{NH}_{3}\right)$, $\mathrm{PM}_{2.5}, \mathrm{PM}_{10}, \mathrm{NO}_{\mathrm{x}}, \mathrm{SO}_{2}$, and VOCs. APEEP includes six categories of criteria air pollution damages related to human health and eight categories of physical impacts such as materials damage; ozone damage to crops and forests; the cost of foregone recreation due to $\mathrm{SO}_{2}, \mathrm{NO}_{\mathrm{x}}$, ozone, and VOCs; and the cost of reduced visibility due to airborne PM.

3 In contrast, some of the European studies, such as the UK government analysis on climate change, estimated the SCC in a range of $\$ 41$ to $\$ 124$ per ton of $\mathrm{CO}_{2}$ with a central value of $\$ 83$ per ton (Bell \& Callan, 2011). 
To transform costs reported in APEEP to national estimates, we weighted the county-level cost estimates by the 2010 county populations (Table 10 ).

Table 10. Population-weighted cost of regulated air emissions

\begin{tabular}{lcc} 
Pollutant & $\begin{array}{c}\text { Population-Weighted Average } \\
\text { Value } \mathbf{( \$ \text { ton } )}\end{array}$ & \$/gram \\
\hline $\mathrm{NH}_{3}$ & $\$ 15,968$ & $\$ 0.0176$ \\
\hline $\mathrm{PM}_{2.5}$ & $\$ 11,926$ & $\$ 0.0132$ \\
\hline $\mathrm{NO}_{\mathrm{x}}$ & $\$ 177$ & $\$ 0.0002$ \\
\hline $\mathrm{SO}_{2}$ & $\$ 4,752$ & $\$ 0.0053$ \\
\hline $\mathrm{VOCs}$ & $\$ 1,333$ & $\$ 0.0014$ \\
\hline $\mathrm{PM}_{10}$ & $\$ 1,826$ & $\$ 0.0020$ \\
\hline
\end{tabular}

Source: Muller and Mendelsohn (2006).

Based on the population-weighted cost of regulated air emission values and the emissions estimates reported in GREET, driving 1,000 miles using conventional gasoline generates external costs of $\$ 11.63$ (Figure 9). The lowest external cost of alternative fuels is estimated to be $\$ 2.94$ per 1,000 miles from an 85 percent ethanol-blend (E85) using woody biomass, such as hybrid poplar as a feedstock. Fuels relying on coal as a significant input in production, such as diesel produced using the Fischer-Tropsch process, impose greater external costs than conventional gasoline or diesel.

For certain feedstocks, regional variation in yields and crop inputs may result in externalities that vary by region. To explore the potential differences, we created a spreadsheet-based tool to change the corn-based ethanol inputs within GREET by region (Figure 10).

The crop input budgets based on different agricultural practices (e.g., irrigation vs. dry-land, tillage practices) for all the US states were obtained from the Forest and Agriculture Sector Optimization Model-Greenhouse Gas Emissions (FASOM-GHG), a dynamic partial equilibrium model used mainly for agriculture and forestry-related environmental policy analyses (Adams, Alig, McCarl, \& Murray, 2005; Beach et al., 2010). Based on our analysis,

\section{Figure 9. Valued externalities of alternative fuels $(2007 \$ / 1,000$ miles)}

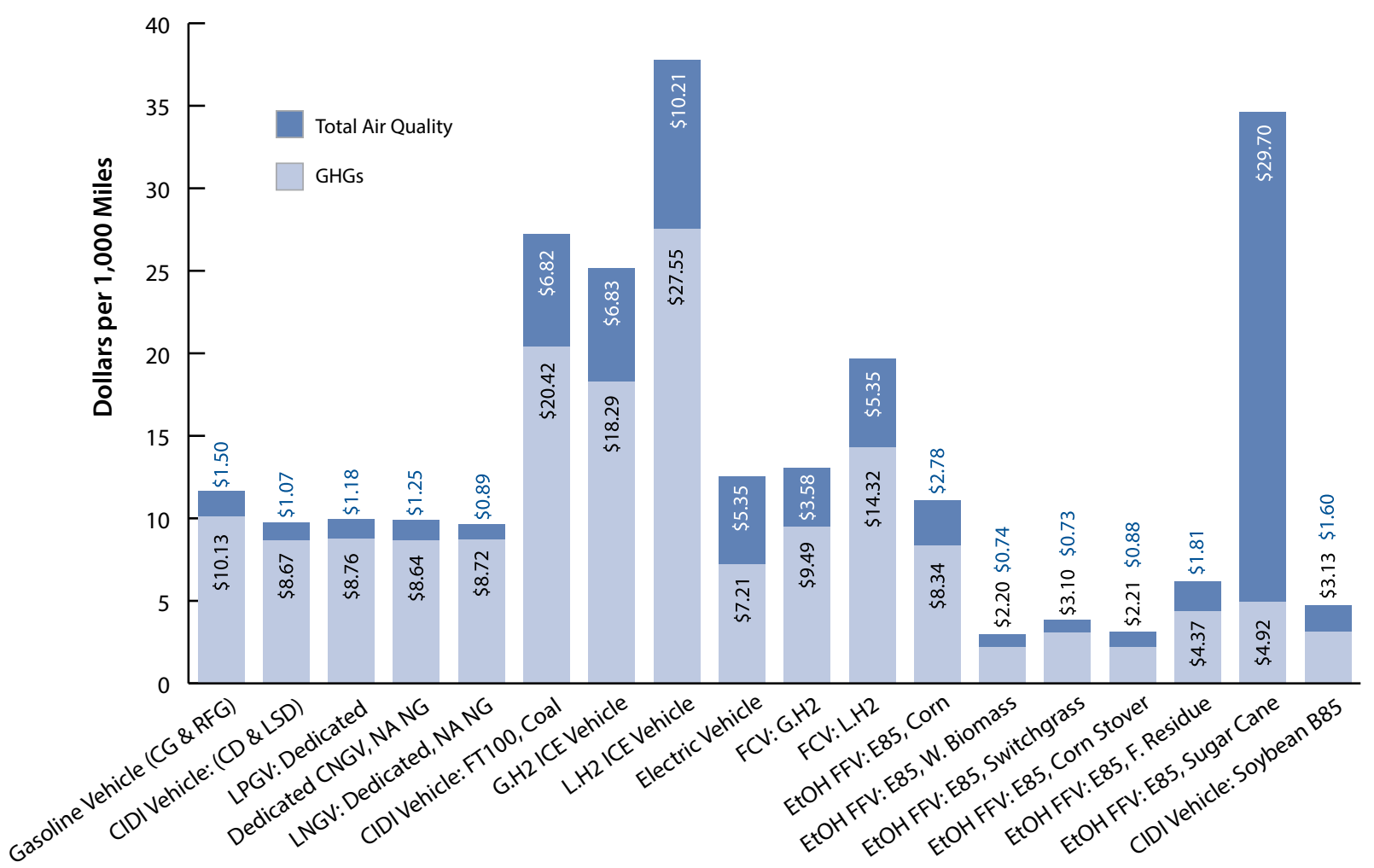

Alternative Fuels 
Figure 10. Spreadsheet tool to estimate regional differences in externalities from feedstocks

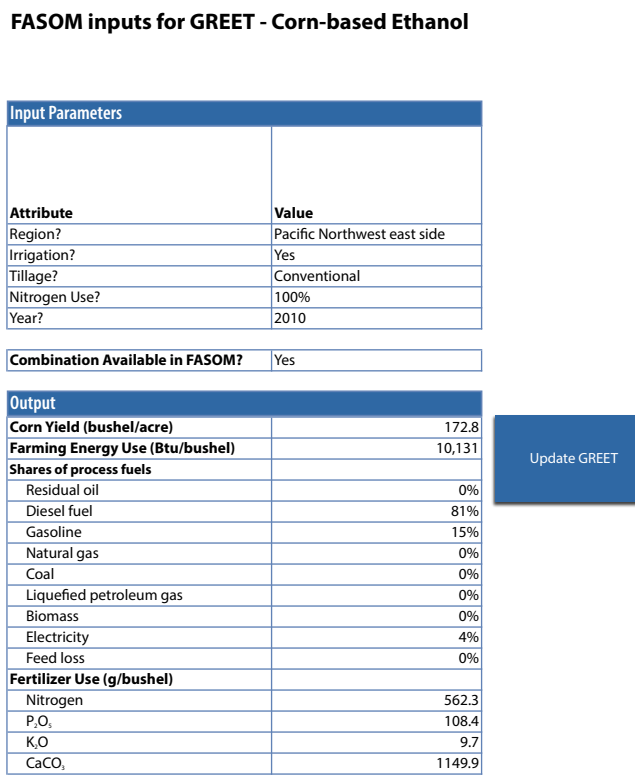

regional differences in corn production did not result in large differences in values of GHG emissions. Ethanol produced using corn from the Lake States region was estimated to have the lowest life-cycle GHG emissions, while ethanol produced using corn from the Pacific Southwest was estimated to have the highest (Figure 11). For corn-based ethanol, differences in life-cycle GHG emissions based on the feedstock region were minimal. Life-cycle GHG emissions from the Pacific Southwest were only 7 percent greater than those from the Lake States.

\section{Estimation of Biodiversity Loss}

To meet the demand for feedstock crops under a large-scale expansion in biofuels production, a combination of a shift in cropping patterns on the existing cropland and a conversion of forest or pasture land into new cropland would need to occur. As the rise in crop prices ripples through the global economy through international trade linkages, the result could be similar land conversion in other countries, which is known as indirect land use change (iLUC). When land is converted from forest or pasture cover, additional
Figure 11. Valued carbon impacts of corn-based E85 (2007\$/1,000 miles) by FASOM-GHG region

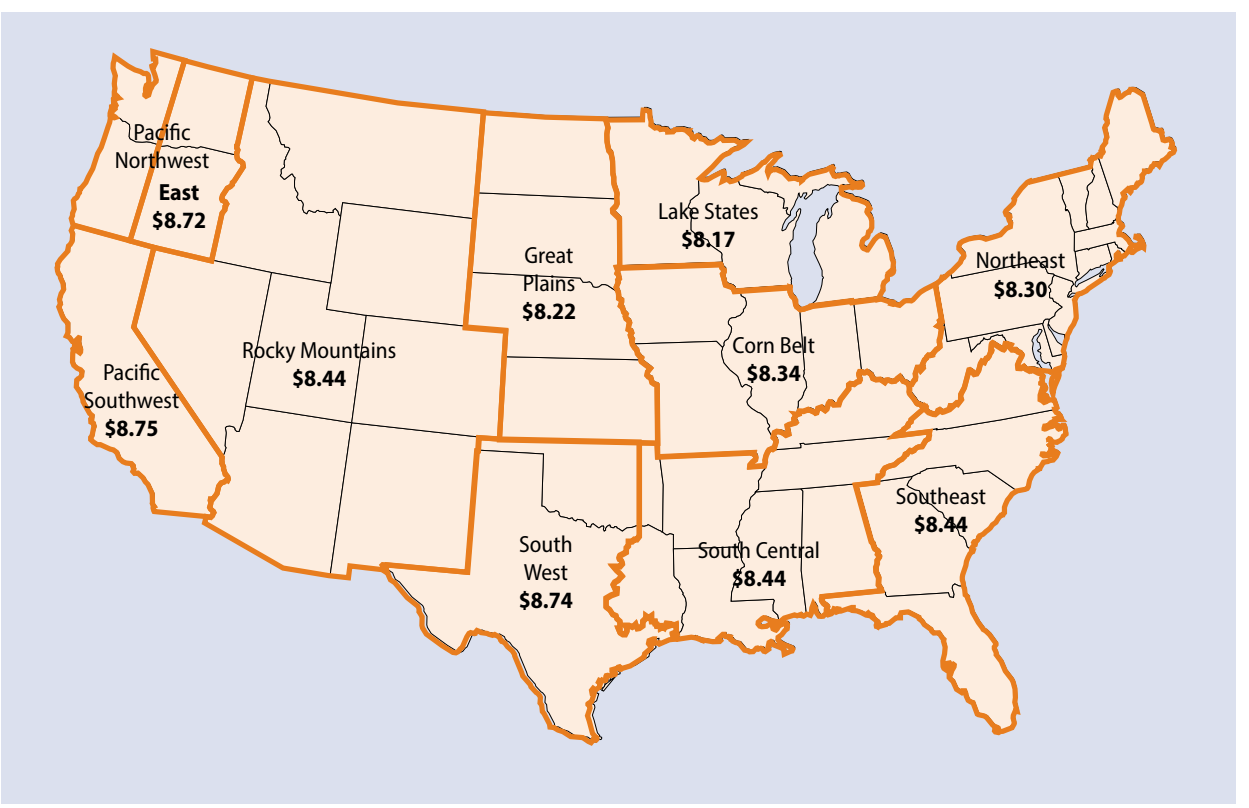


GHG emissions result because of the release of carbon stock from the soil and biomass. Accounting for iLUC-related emissions in assessing biofuels for policy making has been a highly contentious issue. Apart from GHG emissions, this iLUC has other consequences on the environment such as a loss of biodiversity. To estimate the potential magnitude of biodiversity loss associated with the US renewable fuel policy, we used model-predicted global forest cover change due to US renewable fuel policies from the GTAP-BIO model (Birur, 2010). The GTAP-BIO model is a global computable general equilibrium (CGE) model with a focus on biofuels and land use change. We implemented the following policy scenarios: incremental production of corn ethanol in the United States increasing to 15 billion gallons by 2015 , soybean biodiesel to 1 billion gallons, and import of sugarcane ethanol to 1.5 billion gallons. These three biofuels expansion scenarios were implemented separately in the GTAP-BIO model. The resulting changes in global land cover based on the individual biofuel scenario were incorporated into the Open Source Impacts of REDD+ Incentives Spreadsheet (OSIRIS) model for estimating the potential biodiversity loss.

We used estimates of national forest cover and endemic forest dwelling species from OSIRIS (Busch et al., 2010). OSIRIS was used to evaluate the impact of different rates of deforestation on biodiversity. The model was used to evaluate potential impacts of different REDD scenarios on biodiversity on a global scale and also to optimize biodiversity. The extinction rates in the model are estimated using a species-area relationship:

$$
E_{i}=S_{i}\left(1-\left(1-d_{i}\right) z\right.
$$

where $E_{i}$ refers to the rate at which a species is committed to extinction, $S_{i}$ is the current number of forest species in country $i, d_{i}$ is the deforestation rate (percent per year) in country $i$, and the parameter $\mathrm{z}=0.25$ from the archipelagic species area relationship (Kissinger, 2010).

The biodiversity impact from changes in forest cover was estimated within OSIRIS using the species-area curve mentioned above. Our estimated biodiversity impacts of the US biofuels policies were found to be minimal in developing countries. The greatest impact on biodiversity in all scenarios was estimated to take place in Brazil. However, the predicted extinctions are below 0.04 even when sugarcane ethanol is imported into the United States (Table 11). Although the aggregate measure of species extinction has some caveats compared with spatially disaggregated forest loss, the OSIRIS results give a broader picture of the potential impact of policies such as biofuels, which are suspected to affect biodiversity on a global scale.

\begin{tabular}{|c|c|c|c|c|}
\hline Country & Amphibians & Birds & Mammals & Total \\
\hline \multicolumn{5}{|c|}{ Scenario: US Corn Ethanol Production (15 bgy by 2015) } \\
\hline Brazil & 0.00553 & 0.00586 & 0.00706 & 0.01846 \\
\hline Mexico & 0.00407 & 0.00142 & 0.00336 & 0.00885 \\
\hline Madagascar & 0.00127 & 0.00145 & 0.00440 & 0.00712 \\
\hline India & 0.00158 & 0.00168 & 0.00188 & 0.00513 \\
\hline Papua New Guinea & 0.00160 & 0.00079 & 0.00059 & 0.00299 \\
\hline Sri Lanka & 0.00114 & 0.00069 & 0.00040 & 0.00223 \\
\hline Cuba & 0.00119 & 0.00022 & 0.00035 & 0.00177 \\
\hline Tanzania & 0.00069 & 0.00036 & 0.00069 & 0.00174 \\
\hline Democratic Republic of the Congo & 0.00011 & 0.00025 & 0.00091 & 0.00127 \\
\hline Costa Rica & 0.00106 & 0.00004 & 0.00013 & 0.00124 \\
\hline Panama & 0.00058 & 0.00027 & 0.00035 & 0.00119 \\
\hline Jamaica & 0.00049 & 0.00053 & 0.00004 & 0.00106 \\
\hline Guatemala & 0.00088 & 0.00000 & 0.00009 & 0.00097 \\
\hline
\end{tabular}




\begin{tabular}{|c|c|c|c|c|}
\hline Country & Amphibians & Birds & Mammals & Total \\
\hline \multicolumn{5}{|c|}{ Scenario: US Soybean Biodiesel Production (1 bgy by 2015) } \\
\hline Brazil & 0.00194 & 0.00206 & 0.00248 & 0.00649 \\
\hline Indonesia & 0.00079 & 0.00247 & 0.00192 & 0.00518 \\
\hline India & 0.00092 & 0.00098 & 0.00109 & 0.00299 \\
\hline Madagascar & 0.00022 & 0.00025 & 0.00075 & 0.00121 \\
\hline Sri Lanka & 0.00028 & 0.00017 & 0.00010 & 0.00055 \\
\hline Malaysia & 0.00022 & 0.00007 & 0.00020 & 0.00049 \\
\hline Tanzania & 0.00012 & 0.00006 & 0.00012 & 0.00030 \\
\hline Democratic Republic of the Congo & 0.00002 & 0.00004 & 0.00015 & 0.00022 \\
\hline Cameroon & 0.00001 & 0.00003 & 0.00008 & 0.00012 \\
\hline Angola & 0.00000 & 0.00004 & 0.00001 & 0.00006 \\
\hline Ethiopia & 0.00000 & 0.00001 & 0.00004 & 0.00004 \\
\hline Kenya & 0.00000 & 0.00001 & 0.00003 & 0.00004 \\
\hline Nigeria & 0.00000 & 0.00000 & 0.00002 & 0.00002 \\
\hline \multicolumn{5}{|c|}{ Scenario: US Import of Sugar Ethanol (1.5 bgy by 2015) } \\
\hline Brazil & 0.01170 & 0.01241 & 0.01495 & 0.03906 \\
\hline Papua New Guinea & 0.00069 & 0.00034 & 0.00026 & 0.00129 \\
\hline Madagascar & 0.00017 & 0.00020 & 0.00059 & 0.00096 \\
\hline India & 0.00009 & 0.00009 & 0.00011 & 0.00029 \\
\hline Tanzania & 0.00009 & 0.00005 & 0.00009 & 0.00023 \\
\hline Solomon Islands & 0.00000 & 0.00019 & 0.00004 & 0.00023 \\
\hline Democratic Republic of the Congo & 0.00001 & 0.00003 & 0.00012 & 0.00017 \\
\hline Sri Lanka & 0.00008 & 0.00005 & 0.00003 & 0.00016 \\
\hline Cameroon & 0.00001 & 0.00002 & 0.00006 & 0.00010 \\
\hline Angola & 0.00000 & 0.00003 & 0.00001 & 0.00004 \\
\hline Ethiopia & 0.00000 & 0.00000 & 0.00003 & 0.00003 \\
\hline Kenya & 0.00000 & 0.00001 & 0.00002 & 0.00003 \\
\hline Nigeria & 0.00000 & 0.00000 & 0.00002 & 0.00002 \\
\hline
\end{tabular}

\section{Impact of Transportation Fuels on Water Use}

With the growing number of national policies aimed at achieving energy security and reducing environmental and other externalities by developing alternative fuels, the impacts of these new technologies on water use are drawing greater attention from researchers. Until recently, most of the debates on the food vs. fuel issue focused on diverting food grains and cropland for biofuels production. With the rising interest in accelerating the production of unconventional fuels such as shale gas, the dimension of diverting water from farm production to hydraulic fracturing of oil shale has been added to the food vs. fuel debate surrounding expanded use of renewable fuels. Finley (2012) reported that farmers in Colorado face new competition for water use from the fracking industry. The Northern Water Conservancy District auctions excess water diverted from the Colorado River Basin, where farmers have to bid for water along with the energy companies. The average price of water at these auctions has been rising from $\$ 22$ per acre-foot $(326,000$ gallons) in 2010 to $\$ 28$ in early 2012. Although the share of water used by the fracking industry is relatively insignificant, the potential impact on the environment such as ground water contamination, radioactive contamination of water, earthquakes, and GHG emissions, particularly the emission of VOCs affecting health, is still a major concern. 
Using LCA, Wu et al. (2009) examined water use impacts for production of energy feedstocks and fuels. Those authors examined water requirements for five fuel pathways: ethanol from corn, ethanol from cellulosic feedstocks, gasoline from Canadian oil sands, Saudi Arabian crude, and US conventional crude from onshore wells. The fuel life cycle in their study included two major steps: resource extraction (feedstock production, oil recovery) and fuel processing (oil refining) or production (ethanol). The study found that a gallon of corn ethanol production requires about 10 to 324 gallons of water, mainly depending on the feedstock growing region, soil type, and climate (Table 12), whereas water consumption in the gasoline life cycle ranges from 3.4 to 6.6 gallons incurred mainly during the oil recovery process. This range depends on type and source of crude, recovery technology, geological condition, the age of the well, and water reinjection. A similar range of water use is observed during oil-sands recovery. Although ethanol production was found to require a substantial volume of water, most of it is consumed during feedstock production, and only a comparably small volume is required by ethanol plants.

\begin{tabular}{|c|c|c|}
\hline $\begin{array}{l}\text { Fuel } \\
\text { (feedstock) }\end{array}$ & $\begin{array}{l}\text { Net Water } \\
\text { Consumed }\end{array}$ & $\begin{array}{l}\text { Major Factors } \\
\text { Affecting Water Use }\end{array}$ \\
\hline 1. Corn ethanol & $\begin{array}{l}10-324 \mathrm{gal} / \mathrm{gal} \\
\text { ethanol }\end{array}$ & $\begin{array}{l}\text { Regional variation } \\
\text { caused by irrigation } \\
\text { requirements due to } \\
\text { climate and soil types }\end{array}$ \\
\hline 2. Switchgrass ethanol & $\begin{array}{l}1.9-9.8 \mathrm{gal} / \mathrm{gal} \\
\text { ethanol }\end{array}$ & Production technology \\
\hline $\begin{array}{l}\text { 3. Gasoline (US } \\
\text { conventional crude) }\end{array}$ & $\begin{array}{l}3.4-6.6 \mathrm{gal} / \mathrm{gal} \\
\text { gasoline }\end{array}$ & $\begin{array}{l}\text { Age of oil well, } \\
\text { production } \\
\text { technology, and } \\
\text { degree of produced } \\
\text { water recycled }\end{array}$ \\
\hline $\begin{array}{l}\text { 4. Gasoline (Saudi } \\
\text { conventional crude) }\end{array}$ & $\begin{array}{l}2.8-5.8 \mathrm{gal} / \mathrm{gal} \\
\text { gasoline }\end{array}$ & Same as above \\
\hline $\begin{array}{l}\text { 5. Gasoline (Canadian oil } \\
\text { sands) }\end{array}$ & $\begin{array}{l}2.6-6.2 \mathrm{gal} / \mathrm{gal} \\
\text { gasoline }\end{array}$ & $\begin{array}{l}\text { Geologic formation, } \\
\text { production technology }\end{array}$ \\
\hline
\end{tabular}

Source: Wu et al. (2009).

Based on estimates from the literature, Service (2009) compiled water requirements for energy production using fossil fuels as well as renewable fuels normalized based on energy content (Table 13).
Because biofuels are agriculture based, the estimates for production of $1 \mathrm{MWh}$ of soybean-biodiesel energy ranged from 13.9 to 27.9 million liters and that of corn ethanol ranged from 2.3 to 8.7 million liters. Compared with these estimates, the water requirement to produce petroleum fuels on an energy basis was insignificant.

\begin{tabular}{|c|c|}
\hline Method of Energy Production & $\begin{array}{l}\text { Water Requirement } \\
\text { (Liters/MWh) }\end{array}$ \\
\hline Petroleum extraction & $10-40$ \\
\hline Oil refining & $80-150$ \\
\hline Oil shale surface retort & $170-681$ \\
\hline $\begin{array}{l}\text { Natural gas combined cycle power } \\
\text { plant, closed loop cooling }\end{array}$ & $230-30,300$ \\
\hline $\begin{array}{l}\text { Coal integrated gasification combined } \\
\text { cycle }\end{array}$ & $\sim 900$ \\
\hline $\begin{array}{l}\text { Nuclear power plant, closed loop } \\
\text { cooling }\end{array}$ & $\sim 950$ \\
\hline $\begin{array}{l}\text { Geothermal power plant, closed loop } \\
\text { tower }\end{array}$ & $1,900-4,200$ \\
\hline Enhanced oil recovery & $\sim 7,600$ \\
\hline $\begin{array}{l}\text { Natural gas combined cycle, open loop } \\
\text { cooling }\end{array}$ & $28,400-75,700$ \\
\hline Nuclear power plant, open loop cooling & $94,600-227,100$ \\
\hline Corn ethanol irrigation & $2,270,000-8,670,000$ \\
\hline Soybean biodiesel irrigation & $13,900,000-27,900,000$ \\
\hline
\end{tabular}

Source: Service (2009).

\section{Health Impacts of Transportation Fuels}

Studies on human health effects of different transportation fuels are relatively few. Although reductions in GHG emissions from alternative renewable fuels are expected to bring health benefits, some studies contradict this view. For instance, Jacobson (2007) examined the public health risk from projected use of E85 fuel (85 percent ethanol +15 percent gasoline) and found that emissions from E85 may increase ozone-related mortality, hospitalization, and asthma by about 4 percent compared with 100 percent gasoline in the United States. Assessing health effects across different fuels in a consistent manner would significantly contribute to an overall understanding of the transportation sector's effect on health. 
Stark (2010) considered six potential thermochemical biofuels-methanol, ethanol, mixed alcohols, mobile-M synthetic gasoline, FischerTropsch diesel, and dimethyl ether-to analyze the health risks associated with these fuels. The author compared the LD50 (lethal dose that causes death of 50 percent of a group of test animals) health effects of gasoline, diesel, ethanol, and methanol by oral intake, inhalation, and dermal contact on rats, mice, and rabbits. The study reported that methanol toxicity resulting in death as a result of ingestion is comparable to that of other fuels, while methanol is less toxic than gasoline or ethanol in the case of inhalation of the vapors. Overall, the author concluded that all of those biofuels have health risks comparable to or less than their counterparts derived from petroleum. Bromberg and Cheng (2010) indicated that because of the carcinogenic nature of aromatic HCs, high morbidity risks are associated with gasoline and its components. However, methanol is still under toxicological review by US EPA and has not yet been determined to be carcinogenic.

\section{Sustainability Criteria}

As global concerns about the environment and climate change are increasing, energy technologies are often reflected in the ambit of sustainability criteria. A sustainable energy technology may be defined as "the technologies that meet the present energy needs, without compromising the ability of future generations to meet their own needs" (Brundtland, 1987, p. 16). Going by this definition, sustainable energy includes all renewable energy sources and also the technologies that improve energy efficiency, save energy on the demand side, and replace fossil fuels with renewable sources (Lund, 2007).

Because developing and applying sustainability criteria for different transportation fuels was beyond the scope of this study, in this section, we highlight some of the issues concerning sustainable production and consumption of transportation fuels. Based on a literature survey on sustainability in transportation systems, Jeon and Amekudzi (2005) found that although there are no standard definitions, sustainable transportation is characterized as affecting at least three areas: the economy, the environment, and overall social well-being. Because the sustainability criterion of evaluating energy systems is still emerging, the evaluation frameworks are under development. However, some multistakeholder initiatives are underway for establishing sustainability standards for renewable fuels such as biofuels such as the Global Bioenergy Partnership (GBEP) and the Roundtable on Sustainable Biofuels (RSB).

The United Nations Food and Agriculture Organization (UN FAO)-based GBEP Task Force on Sustainability was established in 2008 under the UK's leadership and has developed 24 voluntary sustainability indicators for bioenergy intended to guide bioenergy-related analyses at the UK domestic level. These indicators would help in policy decision making and also facilitate the sustainable development of bioenergy. Similarly, the RSB is an international initiative coordinated by the Energy Center at Ecole Polytechnique Federale de Lausanne in Switzerland. The purpose of this initiative is to develop sustainability standards for biofuels and implement a certification system based on these standards to ensure that biofuels are sustainably produced. To encourage sustainable energy technologies, it is important to use these standards while comparing different transportation fuels.

National policies to reduce dependence on foreign oil and combat GHG emissions have led to the development of alternative liquid fuels for transportation that use domestic resources such as biomass and oil shale. Legislation includes the recent Energy Security and Independence Act of 2007, which was implemented with the goal of promoting secured energy resources. Biofuels (ethanol and biodiesel) produced from agricultural and forest sources have been gaining importance around the world. The IEA estimated that use of biofuels would quadruple between 2008 and 2035, contributing 8 percent of road transport fuel demand by 2035 . It is important to assess transportation fuels from a sustainability standpoint so that environmental externalities are reduced and cost-effective technologies are encouraged.

Apart from the supply-side assessment on sustainability, it is also equally important to gauge consumers' perceptions of emerging energy 
technologies. Rapid adaptation of alternative sources of transportation fuels is also crucial to achieve energy security and reduce GHG emissions. For instance, the US household survey data for 2007 (US Census Bureau, 2008) revealed that about 80 percent of the respondents drove alone to work during the previous week of the survey and only about 7 percent carpooled and 4 percent used mass transportation (Figure 12). These data clearly indicate that personal transportation offers tremendous scope to implement sustainable solutions aimed at reducing our dependence on oil. Therefore, promoting public awareness of alternative fuels and vehicle technologies is much needed. With proven alternative technologies, consumers could bring about a structural shift in energy demand that accelerates the pace of achieving energy security and environmental sustainability.

\section{Figure 12. Principal means of transportation to work in the United States}

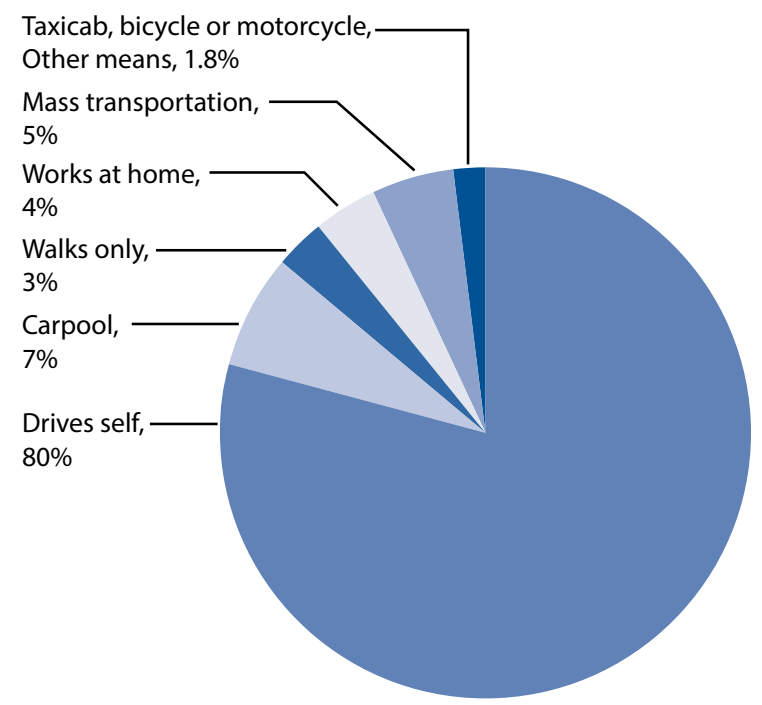

Source: Based on US Census Bureau (2008) survey data.

Sustainability standards applied to not only transportation fuels, but also in other energy sectors as well, could be a catalyst in achieving energy security, while reducing the overall economic and environmental externalities of energy.

\section{Conclusions}

With escalating oil prices, concerns are yet again being raised about the need for reducing our dependence on foreign oil. Several alternative fuel technologies are racing to be a part of the solution to achieve energy security. However, many economic and environmental externalities are associated with different technologies. In this study, we have explored the costs associated with energy security/cost of dependence on oil and estimated the environmental externalities associated with different types of transportation fuels based on a set of economic, environmental, and LCA models.

Our assessment of estimations on oil dependence costs indicates that several elements constitute the true cost of oil, and not many studies have attempted to include all of these costs for various reasons. The share of petroleum imports' costs to US GDP has increased since 2001, implying the degree of dependence on foreign oil. The empirical studies also reveal that whenever the share of oil consumption expenditure to US GDP has crossed 4 percent, the United States suffered a recession. Volatility in oil prices poses a greater threat to economic as well as national security. Although political unrest in some of the MENA countries has been the major reason for the recent higher world price of oil, the weak US dollar has also supported higher oil prices. Several studies have estimated oil security premiums or the marginal external cost of petroleum consumption as the sum of GDP loss and wealth transfers. The monopsony power of the United States also contributes to higher oil prices whenever there is a slight increase in demand. However, it is not treated as an externality in many studies. In addition to these costs, national subsidies are given to transportation fuels that constitute a significant portion of the energy subsidy, and these need to be accounted for in the true cost of oil. Also, one of the key elements of the energy security cost is the national security component. Only a few studies have incorporated the defense expenditure attributed to the cost of securing imported oil. After accounting for these costs, studies have estimated the true or hidden cost to be as high as $\$ 8.35$ per gallon of gasoline. 
To estimate the environmental externalities associated with various transportation fuels, we used GREET, an LCA model; FASOM-GHG, a partial equilibrium dynamic optimization model on agriculture and forestry; APEEP, an integrated assessment model to calculate the marginal damage of emissions; GTAPBIO model, a CGE model to estimate land use and land cover changes due to biofuels policies; and the OSIRIS model, to estimate the species extinctions based on deforestation due to the biofuels policy scenario results. Our estimate of the external cost of driving 1,000 miles was highest using conventional gasoline (\$11.63), while the cost for driving the same distance with E85 fuel derived from woody biomass was cheapest at only $\$ 2.94$ per 1,000 miles.

The FASOM-GHG and GREET-based analysis on incorporating regional variation in yields and crop inputs did not reveal any significant variation across the regions. The GTAP-BIO model-based deforestation rates due to implementation of US RFS2 policies for first generation biofuels, when applied to the OSIRIS model, indicated a very insignificant loss in biodiversity.

Overall, our appraisal of US energy security costs reveals that several studies on this subject have ignored one or more components (e.g., monopoly costs, national security costs) because the issue is complex. Studies on environmental externalities of transportation fuels particularly in recent years have focused heavily on alternative fuels, without evenly accounting for the externalities of petroleum fuels. If all these externality costs were to be internalized, then the price of petroleum fuels in the United States would be much higher. Because internalizing such costs by taxation or rising petroleum prices is politically infeasible in the United States, it would be worth encouraging development and expansion of alternative fuels (both renewable and unconventional fuels) and increasing fuel efficiency using CAFE standards to help reduce petroleum imports and increase energy security.

\section{Recommendations for Further Research}

As the world is witnessing dynamic technological advancement in developing alternative transportation fuels, it is important to analyze and compare the potential of these technologies in a consistent and comprehensive manner. Simultaneous consideration of economic, environmental, and other societal costs within a holistic framework will help answer key questions regarding the relative costs and benefits and suitability of alternative transportation fuels that could play a role in meeting our future energy needs. Given the size of the US oil market, any policy-driven changes in US oil consumption also significantly affect global oil production, the mix of oil resources, and oil price volatility. On this front, it is important to examine the externalities associated with policydriven changes in oil consumption.

Government subsidies/tax credits for biofuels provided in developed countries have also been criticized in the scope of the food vs. fuel debate. However, additional work to account for the implications associated with incentives (subsidies and tax credits) for transportation fuels is necessary. Because military costs are not included in several studies that estimated oil dependence costs, the extent to which military spending could be treated as a fixed versus variable cost is the key factor that needs to be examined. Estimating these true costs in a comprehensive and transparent manner is much needed, because incorporating these externalities could boost the US transition to alternative fuels.

We used a combination of economic, environmental, and LCA models to estimate some of the environmental externalities associated with different fuels. This mechanism could be much further enhanced by linking the models together. Implications of using different transportation fuels on water use and on human health are some of the crucial externalities that have not been investigated thoroughly to date. Further research is needed on this topic. 


\section{References}

Adams, D. M., Alig, R. J., McCarl, B. A., \& Murray, B.C. (2005). FASOMGHG conceptual structure, and specification: Documentation. Unpublished manuscript. College Station, TX: Texas A\&M University. Retrieved from http:// agecon2.tamu.edu/people/faculty/mccarl-bruce/ papers/1212FASOMGHG_doc.pdf

Anair, D., \& Mahmassani, A. (2012). State of charge: Electric vehicles' global warming emissions and fuel-cost savings across the United States. Cambridge, MA: UCS Publications. Retrieved from http://www.ucsusa.org/assets/documents/ clean_vehicles/electric-car-global-warmingemissions-report.pdf

Andrews, S. S. (2006). Crop residue removal for biomass energy production: Effects on soils and recommendations. Washington, DC: USDA, Natural Resource Conservation Service. Retrieved from http://soils.usda.gov/sqi/management/files/ agforum_residue_white_paper.pdf

Argonne National Laboratory (ANL). (2009). Greenhouse Gases, Regulated Emissions, and Energy Use in Transportation (GREET). Computer model, GREET 1.8 c. Argonne, IL: Argonne National Laboratory. Retrieved from http://greet.es.anl.gov/main

Arvizu, D. E., \& Drennen, T. E. (1997). Energy technology progress for sustainable development. Albuquerque, NM: Sandia National Laboratories.

Barsk, R. B., \& Kilian, L. (2004). Oil and the macroeconomy since the 1970s. Journal of Economic Perspectives, 18(4), 115-134.

Beach, R. H., Adams, D. M., Alig, R. J., Baker, J. S., Latta, G. S., McCarl, B. A., ... White, E. M. (2010). Model documentation for the Forest and Agricultural Sector Optimization Model with Greenhouse Gases (FASOMGHG). Research Triangle Park, NC: RTI International. Retrieved from Oregon State University, College of Forestry website: http://www.cof.orst.edu/cof/fr/research/ tamm/FASOMGHG_Model_Documentation_ Aug2010.pdf
Bell, R. G., \& Callan, D. (2011). More than meets the eye-The social cost of carbon in US climate policy, in plain English. Washington, DC: Environmental Law Institute and World Resources Institute. Retrieved from WRI website: http://pdf.wri.org/ more_than_meets_the_eye_social_cost_of_ carbon.pdf

Bernstein, L., Bosch, P., Canziani, O., Chen, Z., Christ, R., Davidson, O., ... Yohe, G. (2007). Climate change 2007: Synthesis report; An assessment of the Intergovernmental Panel on Climate Change. Geneva, Switzerland: Intergovernmental Panel on Climate Change. Retrieved from IPCC website: http://www.ipcc.ch/ pdf/assessment-report/ar4/syr/ar4_syr.pdf

Birur, D. K. (2010). Global impacts of biofuels on agriculture, trade, and environment: $A$ computable general equilibrium analysis (Doctoral dissertation). Purdue University, West Lafayette, IN.

Blanchard, O. J., \& Riggi, M. (2009). Why are the 2000s so different from the 1970s? A structural interpretation of changes in the macroeconomic effects of oil prices. (NBER Working Paper No. 15467). Cambridge, MA: National Bureau of Economic Research.

Brandt, A. (2008). Converting oil shale to liquid fuels: Energy inputs and greenhouse gas emissions of the Shell in situ conversion process. Environmental Science \& Technology, 42(19), 7489-7495.

Brathwaite, J., Horst, S., \& Jacobucci, J. (2010). Maximizing efficiency in the transition to a coalbased economy. Energy Policy, 38, 6084-6091.

Bromberg, L., \& Cheng, W. K. (2010). Methanol as an alternative transportation fuel in the US: Options for sustainable and/or energy-secure transportation. Cambridge, MA: Sloan Automotive Laboratory, Massachusetts Institute of Technology. Retrieved from the Alternative Fuels Data Center website: http://www.afdc.energy.gov/afdc/pdfs/mit_ methanol_white_paper.pdf 
Brown, S. P. A., \& Huntington, H. G. (2010).

Estimating US oil security premiums.

Retrieved from National Energy Policy

Institute website: http://nepinstitute.org/get/

RFF_Reports/Background-Papers/RFF-NEPI-

BrownHuntington-OilSecurity.pdf

Brundtland, H. G. (1987). Our common future.

The United Nations World Commission on

Environment and Development (WCED). New

York: Oxford University Press. Retrieved from http://www.un-documents.net/our-commonfuture.pdf

Busch, J., Strassburg, B., Cattaneo, A., Lubowski, R., Bruner, A., Rice, R. ... Boltz, F. (2010, September). Open source impacts of REDD+ Incentives Spreadsheet (OSIRIS v3.4). Arlington, VA: Collaborative Modeling Initiative on REDD Economics.

Campbell, M. N. (2008). Biodiesel: Algae as a renewable source for liquid fuel. Guelph Engineering Journal, 2, 2-7.

Clark, R. H., T. Stephenson, T., \& Wardle, R. W. M. (2009). Emissions measurements of Shell GTL fuel in the context of on-road trials and laboratory studies. In the Proceedings of 7 th Int. Colloquium, "Fuels." Tech. Akad. Esslingen, Ostfildern, Germany. Chester, UK: Shell Global Solutions. Retrieved from http://www.synthetic-fuels.eu/ documents/20110124104447_Emissions\%20 measurements.pdf

Copulos, M. R. (2003). America's Achilles heel-The hidden costs of imported oil: A strategy for energy independence. Washington, DC: The National Defense Council Foundation. Retrieved from http://www.nceastmgtf.com/modules/evolvecms/ upload/America’s\%20Achilles\%20Heel_ Imported\%20Oil.pdf

Copulos, M. R. (2006, September). Elements of an energy policy to benefit Florida and the nation. Backgrounder. No. 49. Tallahassee, FL: The James Madison Institute.
Copulos, M. R. (2007). The hidden cost of oil: An update. Issue alert. Washington, DC: The National Defense Council Foundation. Retrieved from http://ndcf.dyndns.org/ndcf/energy/NDCF_ Hidden_Cost_2006_summary_paper.pdf

Crane, K., Goldthau, A., Toman, M., Light, T., Johnson, S. E., Nader, A., ... Dogo, H. (2009). Imported oil and US national security. Pittsburgh, PA: Infrastructure, Safety, \& Environment and National Security Research Division, RAND Corporation. Retrieved from the RAND website: http://www.rand.org/pubs/monographs/2009/ RAND_MG838.pdf

Delucchi, M. (2005). The Social-Cost Calculator (SCC): Documentation of methods and data, and case study of Sacramento (Research report UCD-ITSRR-05-18). Davis, CA: Institute of Transportation Studies, University of California, Davis. Retrieved from http://pubs.its.ucdavis.edu/publication_ detail.php?id=61

Department of Trade and Industry. (2004). Environmental impact of the extraction of forestry residues. London, UK: Author. Retrieved from http://webarchive.nationalarchives.gov.uk/+/http:// www.berr.gov.uk/files/file16070.pdf

Deutch, J., Schlesinger, J. R., \& Victor D. G. (2006). National security consequences of US oil dependency (Independent Task Force Report No. 58). New York: Council on Foreign Relations Press. Retrieved from Council on Foreign Relations website: http://www.cfr.org/content/publications/ attachments/EnergyTFR.pdf

Elgowainy, A., Burnham, A., Wang, M., Molburg, J., \& Rousseau, A. (2009). Well-towheel energy use and GHG emissions analysis of plug-in hybrid electric vehicles. Argonne, IL: Argonne National Laboratory. Retrieved from Argonne National Laboratory website: http://www. transportation.anl.gov/pdfs/TA/559.pdf

Elliott, S. A. (2012). An evaluation of the environmental impact of the internal combustion engine vehicle versus the hybrid-electric vehicle. (Unpublished master's thesis). Rensselaer Polytechnic Institute, Hartford, CT. Retrieved from http://www.ewp.rpi. edu/hartford/ ellios/EP/FinalReport.pdf 
E.ON. (2012). The energy trilemma. Retrieved from http://www.eonenergy.com/for-your-business/ Sustainable-solutions/What-we-do/The-energytrilemma

Fehrenbacher, K. (2008, October 14). Wesley Clark: It's about energy independence. GigaOM. Retrieved from http://gigaom.com/cleantech/ general-wesley-clark-its-about-energyindependence/

Ferrell, J., \& Sarisky-Reed, V. (2010). National algal biofuels technology roadmap. Washington, DC: US Department of Energy: Energy Efficiency and Renewable Energy Biomass Program. Retrieved from US Department of Energy website: http:// www1.eere.energy.gov/biomass/pdfs/algal_ biofuels_roadmap.pdf

Finley, B. (2012, April 2). Fracking bidders top farmers at water auction. The Denver Post. Retrieved from http://www.denverpost.com/ entertainmentcolumnists/ci_20306480/frackingbidders-top-farmers-at-water-auction

Five Winds International. (2004). Gas to liquids life cycle assessment-Synthesis report. Retrieved from http://www.sydneypeakoil.com/davek/GTL_ LCA_Synthesis_Report.pdf

Greene, D. L. (2010). Measuring energy security: Can the United States achieve oil independence? Energy Policy, 38, 1614-1621.

Greene, D. L., \& Leiby, P. N. (2006). The Oil Security Metrics Model: A tool for evaluating the prospective oil security benefits of DOE's Energy Efficiency and Renewable Energy R\&D programs. (ORNL/ TM-2006/505). Oak Ridge, TN: Oak Ridge National Laboratory. Retrieved from Center for Transportation Analysis website: http://wwwcta.ornl.gov/cta/Publications/Reports/ORNL_ TM_2006_505.pdf

Greene, D. L., Lee, R. S., \& Hopson, J. L. (2011). OPEC and the costs to the US economy of oil dependence: 1970-2010. Oak Ridge, TN: Oak Ridge National Laboratory.
Hamilton, J. D. (2011, October 18). Oil prices, exhaustible resources, and economic growth. In Handbook of energy and climate change (pp. 1-64). San Diego, CA: Department of Economics, University of California, San Diego.

Hightower, M., Gritzo, L., Luketa-Hanlin, A., Covan, J., Tieszen, S., Wellman, G., ... Ragland, D. (2004). Guidance on risk analysis and safety implications of a large liquefied natural gas (LNG) spill over water. Albuquerque, NM: Sandia National Laboratories.

Hill, J., Nelson, E. Tilman, D., Polasky, S., \& Tiffany, D. (2006). Environmental, economic, and energetic costs and benefits of biodiesel and ethanol biofuels. Proceedings of the National Academy of Sciences (PNAS). 103(30), 1120611210.

Hoch, M. (2010, August 2). New estimate puts Gulf oil leak at 205 million gallons. PBS Newshour. Retrieved from http://www.pbs.org/newshour/ rundown/2010/08/new-estimate-puts-oil-leak-at49-million-barrels.html

Interagency Working Group on Social Cost of Carbon. (2010). Technical support document: Social cost of carbon for regulatory impact analysis under Executive Order 12866. Retrieved from http://www.epa.gov/otaq/climate/regulations/scctsd.pdf

International Energy Agency. (2008). World energy outlook-2008. Paris, France: International Energy Agency. Retrieved from http://www.iea.org/ textbase/nppdf/free/2008/weo2008.pdf

International Energy Agency. (2011a). IEA analysis of fossil-fuel subsidies. Paris, France: International Energy Agency. Retrieved from http://www. worldenergyoutlook.org/media/weowebsite/2011/ ff_subsidies_slides.pdf

International Energy Agency. (2011b). World energy outlook-2011. Paris, France: International Energy Agency. Retrieved from http://www. worldenergyoutlook.org/

Jacobson, M. Z. (2007). Effects of ethanol (E85) versus gasoline vehicles on cancer and mortality in the United States. Environmental Science and Technology, 41(11), 4150-4157. 
Jaramillo, P., Samaras, C., Wakeley, H., \&

Meisterling, K. (2009). Greenhouse gas implications of using coal for transportation:

Life cycle assessment of coal-to-liquids, plug-in hybrids, and hydrogen pathways. Energy Policy, 37, 2689-2695.

Jeon, C. M., \& Amekudzi, A. (2005). Addressing sustainability in transportation systems: Definitions, indicators, and metrics. Journal of Infrastructure Systems, 11(1), 31-50.

Kahn R. S., Kobayashi, S., Beuthe, M., Gasca, J., Greene, D., Lee, D. S., Muromachi, Y., Newton, P. J., Plotkin, S., Sperling, D., Wit, R., \& Zhou P. J. (2007). Transport and its infrastructure. In B. Metz, O. R. Davidson, P. R. Bosch, R. Dave, \& L. A. Meyer (Eds.), Climate change 2007: Mitigation. Contribution of Working Group III to the Fourth Assessment Report of the Intergovernmental Panel on Climate Change (pp. 323-385). Cambridge, UK, and New York: Cambridge University Press. Retrieved from http://www.ipcc.ch/pdf/assessment-report/ar4/ wg3/ar4-wg3-chapter5.pdf

Kingston, P. F. (2002). Long-term environmental impact of oil spills. Spill Science \& Technology Bulletin, 7(1-2), 53-61.

Kissinger, G. (2010). The link between reducing deforestation and forest degradation and biodiversity conservation. Vancouver, BC: Lexeme Consulting. Retrieved from WWF Norway website: http://assets.wwf.no/downloads/redd_ biodiversity_report_technical_background.pdf

Kopits, S. (2009, July 5). What oil price can America really afford? The Cutting Edge. Retrieved from http://www.thecuttingedgenews.com/index. php?article $=11440$

Krauss, C. (2012, January 5). Oil price would skyrocket if Iran closed the Strait of Hormuz. The New York Times. Retrieved from http://www. nytimes.com/2012/01/05/business/oil-pricewould-skyrocket-if-iran-closed-the-strait.html

Kusiima, J. \& Powers, S. (2010). Monetary value of the environmental and health externalities associated with production of ethanol from biomass feedstocks. Energy Policy, 38, 2785-2796.
Lankoski, J., \& Ollikainen, M. (2010). Biofuel policies and the environment: Do climate benefits warrant increased production from biofuel feedstocks? Ecological Economics, 70(4), 676-687.

Larson, E. D. (2006). A review of life-cycle analysis studies on liquid biofuel systems for the transport sector. Energy for Sustainable Development, 10(2), 109-126.

Leiby, P. N. (2008). Estimating the energy security benefits of reduced US oil imports. (ORNL/TM2007/028). Oak Ridge, TN: Oak Ridge National Laboratory.

Levi, M. A. (2010). Energy security: An agenda for research. Working paper. New York: Council on Foreign Relations. Retrieved from Council on Foreign Relations website: http://www.cfr.org/ energy-security/energy-security/p22427

Lloyd, A. C., \& Cackette, T. A. (2011). Diesel engines: Environmental impact and control. Journal of the Air \& Waste Management Association, 54, 809-847.

Loschel, A., U. Moslener, U., \& Rubbelke, D. T. G. (2010). Energy security-Concepts and indicators. Energy Policy, 38(4), 1607-1608.

Lund, H. (2007). Renewable energy strategies for sustainable development. Energy, 32(6), 912-919.

MacLean, H., \& Lave, L. B. (2003). Evaluating automobile fuel/propulsion system technologies. Progress in Energy and Combustion Science, 29, $1-69$.

Mathews, J. A., \& Tan, H. (2009). Biofuels and indirect land use change effects: The debate continues. Biofuels, bioproducts, and biorefining, 3(3), 305317.

Michalek, J.J., Chester, M., Jaramillo, P., Samaras, C., Norman Shiau, C.-S., \& Lave, L. B. (2011). Valuation of plug-in vehicle life-cycle air emissions and oil displacement benefits. Proceedings of National Academy of Sciences, 108(40), 16554-16558. Retrieved from www.pnas. org/cgi/doi/10.1073/pnas.1104473108 
Muller, N., \& Mendelsohn, R. (2006). The Air Pollution Emission Experiments and Policy Analysis Model (APEEP). Retrieved from http:// www.econ.yale.edu/ nordhaus/Resources/ muller_JEEM_Appendix.pdf

National Academy of Sciences. (2009). Hidden costs of energy: Unpriced consequences of energy production and use. Washington, DC: National Research Council of the National Academies, The National Academies Press. Retrieved from http:// media.kentucky.com/smedia/2009/10/19/10/ HiddenCosts.source.prod_affiliate.79.pdf

National Oceanic and Atmospheric Administration. (2008). Office of Exxon Valdez Oil Spill Damage Assessment and Restoration: Research and restoration projects. Retrieved from http://www. fakr.noaa.gov/oil/details.htm

Ogden, J. M., Williams, R. H., \& Larson, E. D. (2007). Societal lifecycle costs of cars with alternative fuels/engines. Energy Policy, 32(2004), 7-27.

Parry, I. W. H., \& Darmstadter, J. (2003). The costs of US oil dependency. Discussion paper 03-59. Washington, DC: Resources for the Future. Retrieved from Resources for the Future website: http://www.rff.org/documents/rff-dp-03-59.pdf

Parry, I. W. H., Walls, M., \& Harrington, W. (2007). Automobile externalities and policies. Journal of Economic Literature, XLV, 373-399.

Pieprzyk, B., Kortluke, N., \& Hilje, P. R. (2009). The impact of fossil fuels-Greenhouse gas emissions, environmental consequences and socio-economic effects. Bruxelles, Belgium: Energy Research Architecture. Retrieved from European Biodiesel Board website: http://www.ebb-eu.org/ EBBpressreleases/ERA\%20Study\%20Impact\%20 of $\% 20$ fossil\%20fuels\%20final\%20report.pdf

Ramey, V. A., \& Vine, D. J. (2011, May). Oil, automobiles, and the US economy: How much have things really changed? NBER Macroeconomics Annual 2010, 25, NBER Chapters Number 12036. Cambridge, MA: National Bureau of Economic Research. Retrieved from National Bureau of Economic Research website: http:// www.nber.org/chapters/c12036.pdf
Rao, V. (2012b, April 4). The road to energy independence. Research Triangle Park, NC: Research Triangle Energy Consortium. Retrieved from Research Triangle Energy Consortium website: http://rtec-rtp.org/2012/04/04/the-roadto-energy-independence/

Sala, O. E., Sax, D., \& Leslie, H. (2009). Chapter 7: Biodiversity consequences of increased biofuel production. In R. W. Howarth \& S. Bringezu (Eds.), Biofuels: Environmental consequences and interactions with changing land use. Proceedings of the Scientific Committee on Problems of the Environment (SCOPE) International Biofuels Project Rapid Assessment (pp. 127-137). Ithaca, NY: Cornell University. Retrieved from http://cip. cornell.edu/biofuels/

Service, R. F. (2009). Another biofuels drawback: The demand for irrigation. Science, 323, 516-517.

Sheehan, J., Aden, A., Paustian, K., Killian, K., Brenner, J., Walsh, M., \& Nelson, R. (2004). Energy and environmental aspects of using corn stover for fuel ethanol. Journal of Industrial Ecology, 7(3-4), 117-146.

Slingenberg, A., Braat, L., van der Windt, H., Rademaekers, K., Eichler, L., \& Turner, K. (2009). Study on understanding the causes of biodiversity loss and the policy assessment framework. (Contract No. DG.ENV.G.1/FRA/2006/0073). The Netherlands: ECORYS Nederland BV. Retrieved from European Commission Directorate-General for Environment website: http://ec.europa.eu/ environment/enveco/biodiversity/pdf/causes_ biodiv_loss.pdf

Southern States Energy Board. (2006, July). Building a bridge to energy independence and to a sustainable energy future American energy security. Norcross, GA: The Southern States Energy Board, American Energy Security. Retrieved from American Energy Security website: http://americanenergysecurity. org/wordpress/wp-content/uploads/2009/02/aesreport.pdf

St. Louis Fed. (2012). Federal Reserve economic data. St. Louis, MO: Economic Research, Federal Reserve Banks of St. Louis. Retrieved from http:// research.stlouisfed.org/fred2/ 
Staley, B. C., Ladislaw, S., Zyla, K., \& Goodward, J. (2009). Evaluating the energy security implications of a carbon-constrained US economy. Issue Brief, Energy Security and Climate Change. Washington, DC: Center for Strategic and International Studies, World Resources Institute.

Stark, A. K. (2010). Multi-criteria lifecycle evaluation of transportation fuels derived from biomass gasification (Master's thesis). Massachusetts Institute of Technology, Cambridge, MA. Retrieved from http://18.7.29.232/bitstream/ handle/1721.1/62870/720919581.pdf?sequence=1

The White House. (2011, March). Blueprint for a secure energy future. Washington, DC. Retrieved from http://www.whitehouse.gov/sites/default/ files/blueprint_secure_energy_future.pdf

Tietenberg, T., \& Lewis, L. (2009). Environmental and natural resource economics. 8th ed. Boston, MA: Pearson Education, Inc.

Tverberg, G. (2012). Why are WTI and Brent prices so different? Retrieved from http://ourfiniteworld. com/2011/02/19/why-are-wti-and-brent-pricesso-different/

US Bureau of Transportation Statistics (2012). Number of US aircraft, vehicles, and other conveyances. Washington, DC: US Department of Transportation. Retrieved from http://www. rita.dot.gov/bts/sites/rita.dot.gov.bts/files/ publications/national_transportation_statistics/ html/table_01_11.html

US Census Bureau. (2008). American housing survey for the United States: 2007. Washington, DC: US Department of Housing and Urban Development and US Census Bureau. Retrieved from http:// www.census.gov/prod/2008pubs/h150-07.pdf

US Defense Logistics Agency. (2010). FY2009 factbook. Fort Belvoir, VA: Defense Logistics Agency-Energy. Retrieved from http://www. energy.dla.mil/library/Pages/Publications.aspx

US Department of Energy. (2010). Hydrogen from coal research. Washington, DC: U.S. Department of Energy, Fossil Energy Office of Communications. Retrieved from http://fossil. energy.gov/programs/fuels/hydrogen/Hydrogen_ from_Coal_R\%26D.html
US Department of Energy. (2011). US billion-ton update: Biomass supply for a bioenergy and bioproducts industry. (ORNL/TM-2011/224). Oak Ridge, TN: Oak Ridge National Laboratory. Retrieved from http://www1.eere.energy.gov/ biomass/pdfs/billion_ton_update.pdf

US Department of Energy, Energy Information Administration. (1996). Alternatives to traditional transportation fuels 1994: Volume 2: Greenhouse gas emissions. Washington, DC: Author. Retrieved from ftp://ftp.eia.doe.gov/pub/solar.renewables/ attf2_94.pdf

US Department of Energy, Energy Information Administration. (2009). Expectations for oil shale production. Washington, DC: U.S. Department of Energy. Washington, DC: Author. Retrieved from http://www.eia.doe.gov/oiaf/aeo/otheranalysis/ aeo_2009analysispapers/eosp.html

US Department of Energy, Energy Information Administration. (2010, April). Alternatives to traditional transportation fuels 2008. Washington, DC: Author. Retrieved from http://www.eia. doe.gov/cneaf/alternate/page/atftables/afv_atf. html\#consumption

US Department of Energy, Energy Information Administration. (2011a). Data on US imports of crude oil by country of origin. Washington, DC: Author. Retrieved from http://205.254.135.7/ dnav/pet/pet_move_impcus_d_NUS_Z00_ mbbl_m.htm

US Department of Energy, Energy Information Administration. (2011b). Direct federal financial interventions and subsidies in energy in fiscal year 2010. Washington, DC: Author. Retrieved from http://www.eia.gov/analysis/requests/subsidy/pdf/ subsidy.pdf

US Department of Energy, Energy Information Administration. (2011c). Performance profiles of major energy producers 2009. Washington, DC: Author. Retrieved from http://www.eia.gov/ finance/performanceprofiles/pdf/020609.pdf 
US Department of Energy, Energy Information Administration. (2012a). Annual energy outlook 2012-Early release. Washington, DC: Author. Retrieved from http://www.eia.gov/forecasts/aeo/ er/

US Department of Energy, Energy Information Administration. (2012b). Petroleum and other liquids. Washington, DC: Author. Retrieved from http://www.eia.gov/petroleum/

US Department of Energy, Office of Energy Efficiency and Renewable Energy. (2003). Just the basics: Liquefied petroleum gas. Washington, DC: Author. Retrieved from http://www1.eere.energy.gov/ vehiclesandfuels/pdfs/basics/jtb_lpg.pdf

US Environmental Protection Agency, Office of Transportation and Air Quality. (2002). Clean alternative fuels: Compressed natural gas. Washington, DC: Author. Retrieved from http:// www.afdc.energy.gov/afdc/pdfs/epa_cng.pdf

US Environmental Protection Agency, Office of Transportation and Air Quality. (2012). Renewable fuel standard. Washington, DC: Author. Retrieved from http://www.epa.gov/otaq/ fuels/renewablefuels/index.htm

US Environmental Protection Agency. (2010, April). Inventory of US greenhouse gas emissions and sinks: 1990-2008. Washington, DC: Author. Retrieved from http://www.epa.gov/ climatechange/Downloads/ghgemissions/508_ Complete_GHG_1990_2008.pdf

US Environmental Protection Agency \& National Highway Traffic Safety Administration. (2010, October). Draft regulatory impact analysis: Proposed rulemaking to establish greenhouse gas emissions standards and fuel efficiency standards for medium and heavy-duty engines and vehicles. (EPA-420-D-10-901). Washington, DC: US Environmental Protection Agency.

US Geological Survey. (2011). Mining water use. Retrieved from http://ga.water.usgs.gov/edu/ wumi.html
Victor, D. (2009). The politics of fossil-fuel subsidies. In Untold billions: Fossil-fuel subsidies, their impacts and the path to reform. Geneva, Switzerland: Global Subsidies Initiative of the International Institute for Sustainable Development. Retrieved from Global Subsidies Initiative website: http://www.globalsubsidies.org/ files/assets/politics_ffs.pdf

Wicks, M. (2009). Energy security: A national challenge in a changing world. London, UK: Department of Energy and Climate Change.

World Energy Council. (2012, November). World energy trilemma 2012. Retrieved from http:// www.worldenergy.org/publications/3962.asp

Wu, M., Mintz, M, Wang, M., \& Arora, S. (2009). Consumptive water use in the production of ethanol and petroleum gasoline. (Report No. ANL/ESD/09-1). Argonne, IL: Center for Transportation Research, Energy Systems Division, Argonne National Laboratory. Retrieved from Argonne National Laboratory website: http://www.transportation.anl.gov/pdfs/AF/557. pdf

Wu, Y., Wang, M., Sharer, \& Rousseau, A. (2006). Well-to-wheels results of energy use, greenhouse gas emissions and criteria air pollutant emissions of selected vehicle/fuel systems. Argonne, IL: Argonne National Library. Retrieved from Argonne National Laboratory website: http://www. autonomie.net/docs/6\%20-\%20Papers/WTW/ wtw_selected_vehicle_fuels_systems.pdf 



\section{Appendix}

Table A-1. Externalities associated with production and use of petroleum-based transportation fuels

\begin{tabular}{|c|c|c|c|c|c|c|c|c|}
\hline Externality & Gasoline $^{\mathrm{a}}$ & Diese $\left.\right|^{\mathbf{b}}$ & $\begin{array}{l}\text { Liquefied } \\
\text { Petroleum } \\
\text { Gas (LPG)c }\end{array}$ & Hydrogend & $\begin{array}{l}\text { Coal to } \\
\text { Liquids (CTL)e }\end{array}$ & $\begin{array}{l}\text { Compressed } \\
\text { Natural Gas } \\
\text { (CNG)f }\end{array}$ & $\begin{array}{l}\text { Gas to } \\
\text { Liquids } \\
\text { (GTL)g }\end{array}$ & $\begin{array}{l}\text { Oil } \\
\text { Shaleh }\end{array}$ \\
\hline $\begin{array}{l}\text { Criteria pollutants } \\
\left(\mathrm{CO}, \mathrm{VOC}, \mathrm{NO}_{x}, \mathrm{SO}_{2}\right. \\
\left.\mathrm{PB}, \mathrm{O}_{3}, \mathrm{PM}\right)\end{array}$ & High & High & $\begin{array}{l}\text { Medium: } \mathrm{SO}_{2} \\
\mathrm{NO}_{x}, \mathrm{CO} \text {; low } \\
\mathrm{PM}\end{array}$ & High: PM & $\begin{array}{l}\text { High: PM; } \\
\text { Medium: CO }\end{array}$ & $\begin{array}{l}\text { Medium: } \\
\mathrm{SO}_{2}, \mathrm{O}_{3}\end{array}$ & $\begin{array}{l}\text { Sulfur } \\
\text { free, } \\
\text { low: CO, } \\
\text { NO, PM }\end{array}$ & High \\
\hline $\mathrm{CO}_{2}$ & High & $\begin{array}{l}\text { Medium: } \\
\text { Lower than } \\
\text { gasoline }\end{array}$ & $\begin{array}{l}\text { Medium: } \\
\text { Combustion }\end{array}$ & $\begin{array}{l}\text { High: If coal } \\
\text { based process. }\end{array}$ & & & & \\
\hline $\begin{array}{l}\text { Low: Natural gas } \\
\text { based }\end{array}$ & $\begin{array}{l}\text { High: Higher } \\
\text { than gasoline }\end{array}$ & $\begin{array}{l}\text { Low: Much } \\
\text { lower than } \\
\text { gasoline } \\
\text { and all } \\
\text { alternatives }\end{array}$ & $\begin{array}{l}\text { Medium: } \\
\text { Lower than } \\
\text { gasoline }\end{array}$ & High & & & & \\
\hline $\begin{array}{l}\text { Hazardous air } \\
\text { pollutant (HAP) }\end{array}$ & High & High & Unknown & High & High & Unknown & Low & High \\
\hline $\mathrm{CH}_{4}$ & High & High & $\begin{array}{l}\text { Medium: } \\
\text { Combustion }\end{array}$ & High & High & High & High & High \\
\hline $\mathrm{N}_{2} \mathrm{O}$ & High & High & $\begin{array}{l}\text { Medium: } \\
\text { Combustion }\end{array}$ & Unknown & Medium & Unknown & Medium & Unknown \\
\hline Erosion & Unknown & - & - & Medium: Coal & Medium: Coal & - & - & High \\
\hline Biodiversity & - & - & - & - & - & - & - & Medium \\
\hline Water usage & High & High & Unknown & High & High & Unknown & High & High \\
\hline $\begin{array}{l}\text { Water quality } \\
\text { damage }\end{array}$ & - & - & Unknown & $\begin{array}{l}\text { High: Aquatic } \\
\text { ecosystems } \\
\text { and water } \\
\text { supply } \\
\text { contamination }\end{array}$ & $\begin{array}{l}\text { High: Aquatic } \\
\text { ecosystems and } \\
\text { water supply } \\
\text { contamination }\end{array}$ & Unknown & High & High \\
\hline $\begin{array}{l}\text { Previously } \\
\text { sequestered carbon } \\
\text { released }\end{array}$ & High & High & High & High & High & - & - & High \\
\hline $\begin{array}{l}\text { Risk to national } \\
\text { security }\end{array}$ & High & High & Unknown & No & No & No & No & No \\
\hline $\begin{array}{l}\text { Dangers associated } \\
\text { with extraction and } \\
\text { transportation of fuel }\end{array}$ & High & - & Unknown & $\begin{array}{l}\text { High: } \\
\text { Extraction }\end{array}$ & High & Medium & Medium & Unknown \\
\hline $\begin{array}{l}\text { Upstream energy } \\
\text { costs }\end{array}$ & High & Medium & Medium & High & High & Unknown & High & High \\
\hline
\end{tabular}


Table A-1. Externalities associated with production and use of petroleum-based transportation fuels (continued)

\begin{tabular}{|c|c|c|c|c|c|c|c|c|}
\hline Externality & Gasoline ${ }^{a}$ & Diese /b & $\begin{array}{l}\text { Liquefied } \\
\text { Petroleum } \\
\text { Gas (LPG)c }\end{array}$ & Hydrogend & $\begin{array}{l}\text { Coal to } \\
\text { Liquids (CTL)e }\end{array}$ & $\begin{array}{l}\text { Compressed } \\
\text { Natural Gas } \\
\text { (CNG)f }\end{array}$ & $\begin{array}{l}\text { Gas to } \\
\text { Liquids } \\
\text { (GTL)g }\end{array}$ & $\begin{array}{l}\text { Oil } \\
\text { Shaleh }\end{array}$ \\
\hline $\begin{array}{l}\text { Susceptibility to } \\
\text { supply disruptions }\end{array}$ & $\begin{array}{l}\text { High: Imports } \\
\text { from unstable } \\
\text { countries, } \\
\text { potential for } \\
\text { embargo }\end{array}$ & No & Unknown & No & No & No & No & No \\
\hline $\begin{array}{l}\text { Infrastructure } \\
\text { adjustments } \\
\text { (transport and } \\
\text { fueling stations) }\end{array}$ & No & No & Unknown & High & Medium & Medium & Low & - \\
\hline Changes to vehicle & No & No & High & High & - & Unknown & No & - \\
\hline
\end{tabular}

a MacLean and Lave (2003); Parry, Walls, and Harrington (2007); Ogden et al. (2007)

b Parry et al. (2007); Ogden et al. (2007); Larson (2006); MacLean and Lave (2003)

c MacLean and Lave (2003)

d US DOE/EIA (2010)

e Brathwaite et al. (2010); Jaramillo et al. (2009)

f Ogden et al. (2007); MacLean and Lave (2003); US DOE/EIA (1996)

$g$ Pieprzyk et al. (2009); Clark et al. (2009); Five Winds International (2004)

h US DOE/EIA (2009); Lankoski and Ollikainen (2010) 
Table A-2. Externalities associated with production and use of renewable transportation fuels

\begin{tabular}{|c|c|c|c|c|c|c|c|}
\hline Externality & $\begin{array}{l}\text { Renewable } \\
\text { Fuels: Traditional } \\
\text { Crops }^{\mathrm{a}}\end{array}$ & $\begin{array}{l}\text { Renewable } \\
\text { Fuels: Energy } \\
\text { Cropsb }\end{array}$ & $\begin{array}{l}\text { Renewable } \\
\text { Fuels: Crop } \\
\text { Residuesc }\end{array}$ & $\begin{array}{l}\text { Renewable } \\
\text { Fuels: Forest } \\
\text { Residuesd }\end{array}$ & Biodiesele & $\begin{array}{l}\text { Algae-Based } \\
\text { Biodieself,g }\end{array}$ & Electric Vehicleh \\
\hline $\begin{array}{l}\text { Criteria pollutants } \\
\left(\mathrm{CO}, \mathrm{VOC}, \mathrm{NO}_{x}, \mathrm{SO}_{2}\right. \\
\left.\mathrm{PB}, \mathrm{O}_{3}, \mathrm{PM}\right)\end{array}$ & $\begin{array}{l}\text { Medium: Lower } \\
\text { than gasoline or } \\
\text { diesel }\end{array}$ & $\begin{array}{l}\text { Medium: Lower } \\
\text { than gasoline } \\
\text { or diesel }\end{array}$ & No & No & Medium & No & $\begin{array}{l}\text { High: Upstream } \\
\text { coal to produce } \\
\text { electricity }\end{array}$ \\
\hline $\mathrm{CO}_{2}$ & $\begin{array}{l}\text { Medium: Lower } \\
\text { than gasoline or } \\
\text { diesel }\end{array}$ & Medium & No & No & $\begin{array}{l}\text { Medium: } \\
\text { Lower than } \\
\text { gasoline or } \\
\text { diesel }\end{array}$ & No & $\begin{array}{l}\text { High: Upstream } \\
\text { coal to produce } \\
\text { electricity }\end{array}$ \\
\hline HAP & Unknown & Unknown & No & No & Medium & No & $\begin{array}{l}\text { High: Upstream } \\
\text { coal to produce } \\
\text { electricity }\end{array}$ \\
\hline $\mathrm{CH}_{4}$ & Medium & Medium & No & No & Unknown & No & $\begin{array}{l}\text { High: Upstream } \\
\text { coal to produce } \\
\text { electricity }\end{array}$ \\
\hline $\mathrm{N}_{2} \mathrm{O}$ & High: Fertilizer & High: Fertilizer & No & No & Medium & No & $\begin{array}{l}\text { Medium: Upstream } \\
\text { coal to produce } \\
\text { electricity }\end{array}$ \\
\hline Erosion & $\begin{array}{l}\text { Medium: Land } \\
\text { clearing }\end{array}$ & $\begin{array}{l}\text { Medium: Land } \\
\text { clearing }\end{array}$ & $\begin{array}{l}\text { Low: If all } \\
\text { residues } \\
\text { removed }\end{array}$ & $\begin{array}{l}\text { Low: If all } \\
\text { residues } \\
\text { removed }\end{array}$ & $\begin{array}{l}\text { Medium: } \\
\text { Land } \\
\text { clearing }\end{array}$ & No & No \\
\hline Biodiversity & $\begin{array}{l}\text { Medium: } \\
\text { Destruction of } \\
\text { habitat for new } \\
\text { crops }\end{array}$ & $\begin{array}{l}\text { Medium: } \\
\text { Destruction of } \\
\text { habitat for new } \\
\text { crops }\end{array}$ & Low & Low & $\begin{array}{l}\text { Medium: } \\
\text { Destruction } \\
\text { of habitat } \\
\text { for new } \\
\text { crops }\end{array}$ & No & No \\
\hline Water usage & $\begin{array}{l}\text { High: Water for } \\
\text { crop production }\end{array}$ & $\begin{array}{l}\text { High: Water } \\
\text { for crop } \\
\text { production }\end{array}$ & No & No & Medium & $\begin{array}{l}\text { Medium: But } \\
\text { could use } \\
\text { wastewater }\end{array}$ & $\begin{array}{l}\text { High: Upstream } \\
\text { coal to produce } \\
\text { electricity }\end{array}$ \\
\hline $\begin{array}{l}\text { Water quality } \\
\text { damage }\end{array}$ & $\begin{array}{l}\text { Medium: Runoff } \\
\text { from fertilizer } \\
\text { application }\end{array}$ & $\begin{array}{l}\text { Medium: Runoff } \\
\text { from fertilizer } \\
\text { application }\end{array}$ & No & No & $\begin{array}{l}\text { Medium: } \\
\text { Runoff from } \\
\text { fertilizer } \\
\text { application }\end{array}$ & Unknown & $\begin{array}{l}\text { High: Upstream } \\
\text { coal to produce } \\
\text { electricity }\end{array}$ \\
\hline $\begin{array}{l}\text { Previously } \\
\text { sequestered carbon } \\
\text { released }\end{array}$ & $\begin{array}{l}\text { Medium: when } \\
\text { lands are cleared } \\
\text { for new crops }\end{array}$ & $\begin{array}{l}\text { Medium: when } \\
\text { lands are } \\
\text { cleared for new } \\
\text { crops }\end{array}$ & No & No & $\begin{array}{l}\text { Medium: } \\
\text { when lands } \\
\text { are cleared } \\
\text { for new } \\
\text { crops }\end{array}$ & No & $\begin{array}{l}\text { High: Upstream } \\
\text { coal to produce } \\
\text { electricity }\end{array}$ \\
\hline $\begin{array}{l}\text { Risk to national } \\
\text { security }\end{array}$ & No & No & No & No & No & No & No \\
\hline $\begin{array}{l}\text { Dangers associated } \\
\text { with extraction and } \\
\text { transportation of } \\
\text { fuel }\end{array}$ & No & No & No & No & No & No & $\begin{array}{l}\text { Medium: Upstream } \\
\text { dangers }\end{array}$ \\
\hline
\end{tabular}


Table A-2. Externalities associated with production and use of renewable transportation fuels (continued)

\begin{tabular}{|c|c|c|c|c|c|c|c|}
\hline Externality & $\begin{array}{l}\text { Renewable } \\
\text { Fuels: Traditional } \\
\text { Crops }^{\mathrm{a}}\end{array}$ & $\begin{array}{l}\text { Renewable } \\
\text { Fuels: Energy } \\
\text { Crops }\end{array}$ & $\begin{array}{l}\text { Renewable } \\
\text { Fuels: Crop } \\
\text { Residuesc }\end{array}$ & $\begin{array}{l}\text { Renewable } \\
\text { Fuels: Forest } \\
\text { Residues }{ }^{d}\end{array}$ & Biodiesele & $\begin{array}{l}\text { Algae-Based } \\
\text { Biodieself,g }\end{array}$ & Electric Vehicle \\
\hline $\begin{array}{l}\text { Substantial } \\
\text { upstream energy } \\
\text { costs }\end{array}$ & $\begin{array}{l}\text { Medium: Fertilizer } \\
\text { production }\end{array}$ & $\begin{array}{l}\text { Medium: } \\
\text { Fertilizer } \\
\text { production }\end{array}$ & No & No & $\begin{array}{l}\text { Medium: } \\
\text { Fertilizer } \\
\text { production }\end{array}$ & Unknown & High \\
\hline $\begin{array}{l}\text { Susceptible to } \\
\text { supply disruptions } \\
\text { (foreign countries) }\end{array}$ & No & No & No & No & No & No & No \\
\hline $\begin{array}{l}\text { Necessary } \\
\text { infrastructure } \\
\text { adjustments } \\
\text { (transport and } \\
\text { fueling stations if } \\
\text { not blending with } \\
\text { gasoline) }\end{array}$ & High & High & High & High & High & High & High \\
\hline $\begin{array}{l}\text { Changes to vehicle } \\
\text { (if not blending } \\
\text { with gasoline) }\end{array}$ & High & High & High & High & High & High & High \\
\hline
\end{tabular}

a Lankoski and Ollikainen (2010); Kusiima and Powers (2010); Hill et al. (2006)

b Lankoski and Ollikainen (2010); Mathews and Tan (2009)

C Lankoski and Ollikainen (2010); Mathews and Tan (2009); Sheehan et al. (2004)

d Kusiima and Powers (2010); Mathews and Tan (2009)

e Kusiima and Powers (2010); Hill et al. (2006); Larson (2006)

f Ferrell and Sarisky-Reed (2010); Campbell (2008)

9 Not enough R\&D has been done to be considered technologically feasible.

h MacLean and Lave (2003) 


\section{Acknowledgments}

We gratefully acknowledge the financial support for this research provided by RTI's Energy Grand Challenge Initiative. We thank James A. Trainham (Lead and Distinguished Fellow), Dorota S. Temple (Scientific Director), and L. Louis Hegedus (Visiting Distinguished Fellow) for their scholarly comments and many valuable discussions during the course of the study. We thank RTI Press Editor-in-Chief Kathleen N. Lohr, Associate Editor George Van Houtven, and Managing Editor Karen Lauterbach for their comments and support during the review process. We also thank the anonymous reviewers for their thoughtful comments and suggestions. 
RTI International is an independent, nonprofit research organization dedicated to improving the human condition by turning knowledge into practice. RTI offers innovative research and technical solutions to governments and businesses worldwide in the areas of health and pharmaceuticals, education and training, surveys and statistics, advanced technology, international development, economic and social policy, energy and the environment, and laboratory and chemistry services.

The RTI Press complements traditional publication outlets by providing another way for RTI researchers to disseminate the knowledge they generate. This PDF document is offered as a public service of RTI International. 